Atmos. Chem. Phys. Discuss., https://doi.org/10.5194/acp-2018-791

\title{
Variations in the physicochemical and optical properties of natural aerosols in Puerto Rico - Implications for climate
}

\author{
Héctor Rivera ${ }^{1}$, John A. Ogren ${ }^{2,3}$, Elisabeth Andrews ${ }^{3}$, Olga L. Mayol-Bracero ${ }^{4}$ \\ 5 'Department of Physics, University of Puerto Rico - Rio Piedras, San Juan, Puerto Rico \\ ${ }^{2}$ Earth Systems Research Laboratory, National Oceanic and Atmospheric Administration, Boulder, Colorado \\ ${ }^{3}$ Cooperative Institute for Research in Environmental Sciences, University of Colorado, Boulder, Colorado \\ ${ }^{4}$ Department of Environmental Sciences, University of Puerto Rico - Rio Piedras, San Juan, Puerto Rico \\ Correspondence to: Olga L. Mayol-Bracero: (omayol@ites.upr.edu)
}

10 Abstract. Since 2005, we have monitored the physicochemical and optical properties of aerosols at the Cape San Juan Atmospheric Observatory, Puerto Rico. Based on the Hybrid Single-Particle Lagrangian Integrated trajectories (HYSPLIT) and satellite imagery from the Volcanic Ash Advisory Center (VAAC) in Washington D.C., Moderate Resolution Imaging Spectroradiometer (MODIS), and Saharan air layer (SAL) images, we grouped natural aerosols in three categories: marine, African dust and volcanic ash. A sun-sky radiometer from the NASA's AErosol RObotic NETwork (AERONET) assessed the total aerosol optical depth and its fine fraction. A 3-wavelength nephelometer and particle soot absorption photometer assessed the scattering and absorption coefficients. Two impactors segregated the submicron $\left(D_{p}<1 \mu \mathrm{m}\right)$ particles from the total $\left(D_{p}<10 \mu \mathrm{m}\right)$ enabling us to calculate the sub-micron scattering and absorption fractions. The measured variables served to calculate the single scattering albedo and radiative forcing efficiency. All variables except the single scattering albedo making up the aerosol climatology for Puerto Rico had different means as function of the aerosol category at $\mathrm{p}<0.05$. For the period $2005-2010$, the largest means $\pm 95 \%$ confidence interval of the scattering coefficient $\left(53 \pm 4 \mathrm{Mm}^{-1}\right)$, absorption coefficient $\left(1.8 \pm 0.16 \mathrm{Mm}^{-1}\right)$, and optical depth $(0.29 \pm 0.03)$, suggested African dust is the main contributor to the columnar and surface aerosol loading in summer. About two thirds (63\%) of the absorption in African dust was due to the coarse mode and about one third due to the fine mode. In volcanic ash, fine aerosols contributed $60 \%$ of the absorption while coarse contributed $40 \%$. Overall, the coarse and fine modes accounted for $\sim 80 \%$ and $20 \%$ of the total scattering. The African dust load was 3.5 times the load of clean marine, 1.9 times greater than the clean marine with higher sea salt content, and 1.7 times greater than volcanic ash. African dust caused 50\% more cooling than that volcanic ash at the top of the atmosphere and 50\% more heating than that of volcanic ash within the marine boundary layer (MBL). 
Atmos. Chem. Phys. Discuss., https://doi.org/10.5194/acp-2018-791

\section{Introduction}

Atmospheric aerosols present high uncertainty in climate prediction (Boucher et al., 2013) because of their differences in amount, in size, and in index of refraction, which in turn depends on the chemical composition and on the source. Different physicochemical properties of aerosols result in diverse optical properties influencing climate and environment in many ways (Seinfeld and Pandis, 1998). Ogren (1995) pointed out that we need to evaluate the aerosols climateforcing properties to know their spatial distribution, their physical, their optical, and their cloud-nucleating properties. We also need to evaluate suitable radiative transfer models, and cloud physics. To contribute with this need, we evaluated the climate-forcing properties of natural aerosols in Puerto Rico.

Extensive research exists on the topic of anthropogenic aerosol climate forcing (Boucher et al., 2013); however, little has been done regarding natural aerosols in the Caribbean. The Caribbean is exposed to different natural aerosols such as those coming from marine sources, mineral dust from Africa and volcanic ash from the Soufriere Hills volcano in the island of Montserrat (e.g., Li-Jones and Prospero, 1998; Gioda et al., 2011; Prospero and Mayol-Bracero, 2013; ValleDiaz et al., 2016; Wex et al., 2016). These three types of aerosols are the focus of this study.

For marine aerosols, oceans produce the greatest primary aerosol mass emissions (Warneck 1988) and are a key source of secondary atmospheric aerosols (O'Dowd and Smith, 1993; O’Dowd et al., 2004). The mass concentration and size distribution of marine aerosols depend on the wind speed (Woodcock, 1953; Lovett, 1978; Blanchard and Woodcock, 1980). Wind speed correlates directly with the sea-salt amount, but wind speed only explains part of the variance (Quinn and Coffman, 1999; Smirnov et al., 2003). Sea-salt is non-absorbing and comprises much of the MBL aerosol mass, changing the radiative balance through scattering of visible light (Quinn et al., 1996; Winter and Chýlek, 1997). The sub-micron non-sea salt (nss) sulfate from biological activity scatters visible light efficiently also serving as cloud condensation nuclei (Charlson et al., 1991; Jacobson, 2001).

Turning to African dust, hundreds of teragrams of it reach the atmosphere every year (Huneuus et al., 2011), with large variations in emissions, in space and in time (Prospero, 1999; Vinoj et al., 2004). These pace-time changing amounts result in poorly characterized African dust radiative-forcing properties (Liao and Seinfeld, 1998; Sokolik and Toon, 1999; Sokolik et al., 2001, which in turn reduces the accuracy of numerical models for predicting climate change (Houghton et al., 2001). In addition, African dust changes the radiative balance scattering and absorbing solar and terrestrial radiation. The dominant absorbing species in African dust are the iron oxides (Sokolik and Toon, 1999; Moosmüller et al., 2009).

Such as African dust, volcanic aerosols change the Earth's radiative balance by scattering and by absorbing solar radiation (Bohren and Huffman, 1999) because volcanic aerosols can hold volcanic ash that in turn holds iron oxides that absorb sunlight (Seinfeld and Pandis, 1998; Kokhanovsky, 2008). Volcanic ash is hard, abrasive, and acidic (Krotkov et al., 1999; Housley et al., 2002) resulting in an aviation hazard. Evidence has shown engine failure in aircrafts flying through volcanic ash (Krotkov et al., 1999; USGS Fact Sheet, 2006).

Aerosols studies in the Caribbean goes back to the 1970s when Prospero et al. (1970) and Prospero and Carlson (1972) highlighted that synoptic outbreaks of Saharan dust that occur from late spring to fall. These outbreaks extend from western Africa across the tropical Atlantic to the Caribbean. Other studies of transported African dust in the Caribbean, 

remote sensing instruments such as Lidars (Burton et al., 2015). From these studies, we highlight the Puerto Rico Dust Experiment (PRIDE) (Reid et al., 2003a, b), the only study that included the radiative, microphysical, and transport properties of African dust. Reid et al. (2002) reported that during the first half of PRIDE (June 2000), dust had the highest concentrations in the marine and convective boundary layers, with lower dust concentrations above the trade inversion despite a strong Saharan Air Layer (SAL). PRIDE showed that coarse marine aerosols produced most of the scattering and optical depth in Puerto Rico. However, the African dust coarse mode generates most of the optical depth in spring and summer (Reid et al., 2003b). Also, with single-particle analyses E. A. Reid et al. (2003) reported that elemental iron composes $\sim 2.5-3 \%$ of the total dust mass (assuming aluminum is $8 \%$ of the total mass). PRIDE excluded characterizing volcanic ash and characterizing the long-term variability of the climate-forcing properties of aerosols in Puerto Rico.

In this article, we characterize the climate-forcing properties of natural aerosols in Puerto Rico. We analyze aerosol data collected in Puerto Rico from 2005-2010 to: 1) classify local aerosols by source (marine, African dust and volcanic ash), 2) characterize means and variabilities in climate-forcing properties of aerosols from these three natural sources and report the monthly climatology of aerosols in Puerto Rico, 3) test the hypothesis that "means and variability of aerosols from different sources differ significantly at $\mathrm{p}<0.05$ ", and 4 ) determine if we can distinguish the kind of aerosol only knowing their mean and variability in the direct climate-forcing properties.

\section{Experimental}

The sampling site was the Cape San Juan Atmospheric Observatory, at the natural reserve of Cabezas de San Juan, Puerto Rico (CPR), with coordinates $\left(18^{\circ} 22.85^{\prime} \mathrm{N}, 65^{\circ} 37.07^{\prime} \mathrm{W}\right)$, managed by the Atmospheric Chemistry and Aerosols Research group at the University of Puerto Rico - Rio Piedras Campus, and supported by the Aerosol Group of the Global Monitoring Division at the National Oceanic and Atmospheric Administration's Earth System Research Laboratory (NOAA/ESRL). CPR is a coastal site influenced by the trade winds most of the year where the absence of large land areas upwind reduces anthropogenic aerosols. African dust disturbs the marine environment of CPR from late spring to mid fall with stronger events in late spring and summer. Emissions from the Soufriere Hills volcano in Montserrat also disturb CPR if the low-level winds are southeast because Puerto Rico is about $400 \mathrm{~km}$ northwest of Montserrat.

\subsection{In-situ aerosol measurements}

Delene and Ogren (2002) have described the aerosol monitoring. The TSI model 3563 integrating nephelometer measures the aerosol scattering $\left(\sigma_{\mathrm{sp}}\right)$ and backscattering $\left(\sigma_{\mathrm{bsp}}\right)$ coefficients at 450,550 and $700 \mathrm{~nm}$. In addition, a Radiance Research Particle Soot Absorption Photometer (PSAP) measures the aerosol absorption coefficient $\left(\sigma_{\text {ap }}\right)$ at 467,530 , and $660 \mathrm{~nm}$. The absorption at $530 \mathrm{~nm}$ was adjusted by $\log -\log$ interpolation to $550 \mathrm{~nm}$ to yield $\sigma_{\mathrm{ap}}$ and $\sigma_{\mathrm{sp}}$ at the same wavelength $(550 \mathrm{~nm})$. Upstream of the nephelometer and PSAP a heater warms the aerosol sample to reduce the relative humidity to values around $40 \%$. Two switched impactors segregate the aerosols in sub-micron $\left(D_{p}<1 \mu \mathrm{m}\right)$ and total $\left(D_{p}<10 \mu \mathrm{m}\right)$ fractions to compare the fine with the total aerosol contributions. 


\subsubsection{Description of in-situ variables}

Variables $\sigma_{\mathrm{sp}}, \sigma_{\mathrm{ap}}$ and extinction coefficient $\left(\sigma_{\mathrm{ext}}\right)$ are extensive parameters (Ogren, 1995). Extensive parameters depend on aerosol amount and are additive. We report $\sigma_{\mathrm{sp}}$ and $\sigma_{\mathrm{ap}}$ in $\mathrm{Mm}^{-1}\left(1 \mathrm{Mm}^{-1}=10^{-6} \mathrm{~m}^{-1}\right)$.

5 Calculating the sub-micron scattering $\left(\mathrm{R}_{\mathrm{sp}}\right)$ and absorption $\left(\mathrm{R}_{\mathrm{ap}}\right)$ fractions allowed us to test the contribution of the submicron mode to the total scattering or to the total absorption. The $\mathrm{R}_{\mathrm{sp}}$ and $\mathrm{R}_{\mathrm{ap}}$ are intensive (i.e., independent of aerosol amount) and non-dimensional parameters associated with the scattering or absorbing particles size distributions (Ogren 1995). Intensive and extensive parameters are variables in chemical transport and radiative transfer models. We calculated $R_{s p}$ and $R_{a p}$ with Eqns. (1) and (2) from Delene and Ogren (2002).

10

$\mathrm{R}_{\mathrm{sp}}\left(\mathrm{D}_{\mathrm{p}}\right)=\frac{\sigma_{\mathrm{sp}}\left(\mathrm{D}_{\mathrm{p}}<1 \mu \mathrm{m}\right)}{\sigma_{\mathrm{sp}}\left(\mathrm{D}_{\mathrm{p}}<10 \mu \mathrm{m}\right)}$

$\mathrm{R}_{\mathrm{ap}}\left(\mathrm{D}_{\mathrm{p}}\right)=\frac{\sigma_{\mathrm{ap}}\left(\mathrm{D}_{\mathrm{p}}<1 \mu \mathrm{m}\right)}{\sigma_{\mathrm{ap}}\left(\mathrm{D}_{\mathrm{p}}<10 \mu \mathrm{m}\right)}$

15 The scattering Ångström exponent (å) is an intensive parameter describing the spectral dependence of the scattering (Eqn. (3))

$\sigma_{\mathrm{sp}}=\mathrm{B} \lambda^{-\mathrm{a}}$

with $\sigma_{\mathrm{sp}}$ the scattering coefficient, B the scattering coefficient at a wavelength $\lambda$ of one $\mu \mathrm{m}$, and å the scattering Ångström exponent. We calculated the scattering Ångström exponent with Eqn. (4).

$\mathrm{a}=-\frac{\log \left(\sigma_{\mathrm{sp}}^{550} / \sigma_{\mathrm{sp}}^{700}\right)}{\log \left(\frac{500}{700}\right)}$

25 In Eqn. (4), $\sigma_{s p} p^{50}$ and $\sigma_{s p} 700$ are the scattering coefficients at 550 and $700 \mathrm{~nm}$. The scattering Ångström exponent qualitatively measures the sizes of scattering particles. The scattering Ångström exponent å varies with the particle size distribution such that lower Ångström exponents are due to distributions dominated by larger scattering particles, and vice versa.

30 In addition, we calculated the single scattering albedo $\left(\omega_{0}\right)$, a non-dimensional intensive quantity, to estimate the contribution of scattering to extinction with Eqn. (5).

$\omega_{0}=\frac{\sigma_{\mathrm{sp}}}{\sigma_{\mathrm{ap}}+\sigma_{\mathrm{sp}}}$

35 The $\omega_{0}$ is part of the radiative forcing per unit of optical depth $(\triangle \mathrm{RF} / \mathrm{AOD})$ at the top of the atmosphere, called radiative forcing efficiency after Sheridan and Ogren (1999). The $\triangle \mathrm{RF} / \mathrm{AOD}$ depends on the aerosol size through the upscatter fraction $\beta$, the scattering and absorption through $\omega_{0}$, and on seven geophysical quantities. We calculated the upscatter fraction with Eqn. $\beta=0.0817+1.8495 \mathrm{~b}-2.9682 \mathrm{~b}^{2}$, where the backscatter fraction $\mathrm{b}$ was calculated with Eqn. $\mathrm{b}=$ 

angle. The radiative forcing efficiency for daytime-average was calculated with Eqn. (6).

$\frac{\Delta \mathrm{RF}}{\mathrm{AOD}}=-\mathrm{DS}_{0} \mathrm{~T}_{\mathrm{at}}^{2}\left(1-\mathrm{A}_{\mathrm{c}}\right) \omega_{0} \beta\left\{\left(1-\mathrm{R}_{\mathrm{s}}\right)^{2}-\left(2 \frac{\mathrm{R}_{\mathrm{s}}}{\beta}\left[\left(\frac{1}{\omega_{0}}\right)-1\right]\right)\right\}$

5

Eqn. (6) assumes a constant geographical surface reflectance $\left(R_{s}\right)$ and atmospheric transmission $\left(T_{\mathrm{at}}\right)$, with the values for the fractional day length $(\mathrm{D})=0.5$, solar constant $\left(S_{\mathrm{o}}\right)=1370 \mathrm{~W} \mathrm{~m}^{-2}, T_{\text {at }}=0.76$, fractional cloud amount $\left(A_{c}\right)=0.6$, and $R_{s}=0.15$ such as proposed by Haywood and Shine (1995). The aerosol measurements are at $550 \mathrm{~nm}$ (Delene and Ogren, 2002).

\subsection{Ground-based remote aerosol measurements}

A CIMEL Electronique 318A spectral radiometer, part of NASA's AErosol RObotic NETwork (AERONET) Cape_San_Juan (CPR) station, assessed the total aerosol optical depth (AOD) and aerosol optical depth fine fraction (AODFF). Holben et al. (1998) detail how to find AOD. The total aerosol optical depth AOD is the integral in the vertical of $\sigma_{\mathrm{ext}}, \lambda$, AOD is a non-dimensional extensive parameter. AERONET finds the fine fraction with the Spectral Deconvolution Algorithm (SDA; O’Neill, 2001, 2003). Also, AERONET uses the number size distributions to derive the volume size distribution through an inversion algorithm by Dubovik and King (2000). AERONET columnar measures include AOD at 1020, 870, 675, 500, 440, 380, and $340 \mathrm{~nm}$. We used AOD at $500 \mathrm{~nm}$ to compare with the $\sigma_{\mathrm{sp}}$ at $550 \mathrm{~nm}$.

\subsection{Models and satellite data}

We used the Hybrid Single Particle Lagrangian Integrated Trajectory (HYSPLIT) Model (Draxler and Hess, 1998;

Draxler and Rolph, 2013) to estimate trajectories of aerosols from the sources to CPR. Moderate Resolution Imaging Spectroradiometer (MODIS) images served to sense possible African dust, volcanic emissions, or clean marine. SAL images proved useful to sense possible African dust over CPR. We used SAL images from http://tropic.ssec.wisc.edu/archive/. Images from the Volcanic Ash Advisory Center (VAAC) in Washington D.C. served to sense volcanic ash if MODIS images were unavailable. VAAC obtains data from three Geostationary Operational Environmental Satellite (GOES) satellites (GOES-11, 10 GOES-12, and GOES-13) covering from the central Pacific to the eastern Atlantic.

\subsection{Data processing and quality control}

35 Nephelometer data were corrected for instrumental non-idealities, such as truncation error, after Anderson and Ogren (1998). The method corrects scattering measurements over integration angles of $\sim 7^{\circ}-170^{\circ}$ and $\sim 90^{\circ}-170^{\circ}$ to the full $0^{\circ}-$ $180^{\circ}$ and $90^{\circ}-180^{\circ}$ ranges, based on the measured scattering Ångström exponent (å). The scattering Ångström exponent qualitatively describes the scattering particles sizes (Anderson and Ogren, 1998). Concerning particles larger than the scattered light wavelength, the truncation error is greater than that of other systematic errors and can become greater by

40 a factor of two. Uncertainties also arise because the nephelometer is calibrated with a gas (Carbon dioxide), which scatters in a Rayleigh regime, and aerosols scatter in the Mie regime. Scattering from gas molecules (Rayleigh scattering) 

aerosols on the filter before applying correction. Ogren (2010) extended the Bond et al. (1999) corrections to apply to measurements of a 3-wavelength PSAP. We manually edited one-minute data from the nephelometer and PSAP to invalidate bad data associated with equipment maintenance and malfunction. The edited 1-minute data files were averaged to create the daily averaged data files. In addition, we checked for consistency of data and impossible values such as $R_{\mathrm{sp}}, \omega_{\mathrm{o}}>1$. We kept these data in the database but omitted them from the plots. In our dataset the measurements of absorption and its related variables began in 2006. We used AERONET level 2 data, screened for clouds and quality assured by NASA (Holben et al., 2006).

\section{Results and Discussion}

First, we describe how we assigned the aerosol categories and a few exceptions to the method. Second, we analyze means and variations in the climate-forcing properties, discussing how the differences in the means and the variations among aerosol categories support or contradict our hypothesis. Finally, we discuss the monthly variation of the climate-forcing properties. For all aerosol categories the trajectories chosen were at 100, 500 and $1000 \mathrm{~m}$ in height.

\subsection{Aerosol Classification by Source}

We present our criteria to label aerosol categories in Table 1, and the sequence of steps followed is presented as a flowchart in Table 2. The method, however, produces uncertainty because we classified average categories in a 24hbasis, but MODIS images are unavailable at night.

\subsubsection{Clean marine aerosols}

Clean marine $(\mathrm{CM})$ aerosols form in the ocean with imperceptible influence from other categories, natural or anthropogenic, with $\sigma_{\mathrm{sp}} \leq 20 \mathrm{Mm}^{-1}, \sigma_{\mathrm{ap}} \leq 0.6 \mathrm{Mm}^{-1}, \mathrm{AOD} \leq 0.1$, and trajectories only over the ocean. Trajectories were at 06 and $12 \mathrm{Z}$ for 100,500 and $1000 \mathrm{~m}$ above sea level. The clean marine with greater sea salt content (CMS) aerosol met the criteria in $\mathrm{CM}$ but, $\sigma_{\mathrm{sp}}>20 \mathrm{Mm}^{-1}$ and AOD $>0.1$. This definition was based on reports by Kleefeld et al. (2002) on the dependence $\sigma_{\mathrm{sp}}$ with wind speed (square of the speed) and Lewis and Schwartz (2004) that wind speed is a main driver producing natural marine aerosols. VAAC and MODIS images served to verify non-marine aerosols.

\subsubsection{African dust}

To find African dust (AD), we searched MODIS images for dust clouds leaving western Africa in spring, summer, and fall (see Table 1). If we saw elevated aerosol loads in Puerto Rico about 6-7 days later, we classified as African dust. An example is the dust cloud over Dakar in May 28, 2010 (Figure 1a), seen over Puerto Rico on June 3, 2010 (Figure 1b). $\mathrm{AD}$ in Figures $2 \mathrm{a}$ and $2 \mathrm{~b}$ was, as in other $\mathrm{AD}$ events, light brown covering large areas of the Caribbean and Atlantic. $\mathrm{AD}$ trajectories were from the east, east-southeast, or southeast. Strong AD episodes such as the event on June 3, 2010 were easily identifiable with MODIS. 


\subsubsection{Volcanic aerosols}

We assigned volcanic aerosols (VA) if the Soufriere Hills' volcano emitted simultaneously with southeast low-level winds, trajectories, and cloud streaks orientation (see Table 1). Figure 2 shows an example during January 9, 2007. We

5 also used cloud streak orientations to estimate the prevailing wind direction because cloud streaks orient parallel to the prevailing winds.

\subsubsection{North America and South America categories}

10 The category from North America occurred more in winter or fall, associated with the cold fronts general circulation, as HYSPLIT trajectories suggested. We linked the South America category with the broad circulation of cyclones north of Puerto Rico promoting southerly low-level winds. We excluded the North and South America category because they only occurred a few times.

\subsubsection{Exceptions to the classification method}

The classification criteria (Table 1) is objective, and a subjective assessment of the classification results led to changes in the assigned classes a few times. Volcanic aerosols reach CPR if the Soufriere Hills' volcano emits simultaneously with southeast low-level winds, cloud streaks and trajectories. One exception is when the ash is already in the Atlantic northeast of Puerto Rico (Figure 3). In this instance, winds shifting to the northeast can bring volcanic ash to Puerto Rico.

Also, we used SAL images cautiously because of the existence of specific cases that MODIS suggested heavy dust (Figure 4a) over Puerto Rico but SAL images suggested no dust (Figure 4b). Also, Figures 5a and 5b show cloud streaks oriented from northeast to southwest instead of southeast to northwest but we classified as AD because AD was clear. This example suggests that African dust can be transported from the Atlantic to CPR.

\subsection{Extensive variables by aerosol category}

\subsubsection{Scattering $\left(\sigma_{\mathrm{sp}}\right)$ and absorption $\left(\sigma_{\mathrm{ap}}\right)$ coefficients}

Figure 5a shows the $\sigma_{\mathrm{sp}}$ frequency distributions for $\mathrm{AD}$ and for $\mathrm{VA}$. We verified that these distributions are log-normal by taking the logarithm of the data and applying a normality test. For $\mathrm{AD}$, the greater number of measurements ranged from $\sim 10$ to $100 \mathrm{Mm}^{-1}$ with fewer extremes showing gaps between them. Statistically, the gaps in the AD frequency distribution suggest that the more extreme $\mathrm{AD}$ events might have distinct causes. But studying the potential causes was out of our scope. Alternatively, the extreme events might all have the same cause, but the study period was insufficient to fill in the gaps. Figure 5a shows that $\mathrm{AD}$ had a greater range in the strength of $\sigma_{\mathrm{sp}}\left(230 \mathrm{Mm}^{-1}\right)$ in contrast to that of 75 $\mathrm{Mm}^{-1}$ for VA.

Table 3 summarizes aerosol data collected from 2005-2010. Comparing the aerosol loads among aerosol categories within the MBL, we found that mean $\sigma_{\mathrm{sp}}$ for $\mathrm{AD}$ was significantly greater than mean $\sigma_{\mathrm{sp}}$ otherwise (3.5 times greater than CM, 1.9 times greater than CMS with greater sea salt content and 1.7 times greater than VA). Hence, mean 

number of $\mathrm{AD}$ events ranged from 30 to $35 \mathrm{Mm}^{-1}$ and regarding the VA case it ranged from 15 to $20 \mathrm{Mm}^{-1}$. Mean $\sigma_{\mathrm{sp}}$ between $\mathrm{AD}$ and VA differed by $23 \mathrm{Mm}^{-1}$ with a $95 \%$ confidence interval (CI) from 16.8 to $27.8 \mathrm{Mm}^{-1}$. These results support our hypothesis about aerosol loads. Figure $5 \mathrm{~b}$ shows the frequency distribution for CM and for CMS. The coefficients of variation (the standard deviation over the mean) were smaller in the marine aerosols with $21 \%$ for $\mathrm{CM}$ and $22 \%$ for CMS. The coefficient of variation for AD was $65 \%$ and for VA (51\%). Thus, AD and VA had coefficients of variation 3.1 and 2.4 times greater than those of the marine aerosols, respectively.

About the columnar data, Figure 6a shows a VA event for which Figure $6 \mathrm{~b}$ shows the corresponding volume size distribution dominated by fine aerosols (i.e. not the marine aerosols). Many studies regarding volcanic ash particles indicate the presence of coarse mode particles inside the plume. Due to gravitational settling and meteorological conditions the coarser particles fall earlier, while the finer travel longer distances. Thus, the aging of such aerosols affects the sizes of the detected VA particles. Trajectories of 1-3 days allowed coarse particles to fall and fine particles to reach Puerto Rico (Mather et al., 2003). Also, dome-forming eruptions of highly crystalline magma, such as that at the Soufriere volcano in Montserrat, release much fine ash (Baxter et al., 1999; Moore et al., 2002; Bonadonna et al., 2002; Bonadonna et al., 2005). In contrast, for the VA event shown in Figure 6c, the volume size distribution (Figure 6d) shows coarse aerosols (such as the marine aerosols) dominating the volume. These results imply that VA events are variable enough that sometimes VA dominates the column loading and sometimes sea-salt dominates, implying that two distinct aerosols are present in the VA category. However, the optical data in Table 3 shows that VA dominates the light scattering during VA events because the light scattering efficiency of coarse-mode particles is much lower than that of fine-mode particles. Therefore, in some VA events, sea-salt might dominate the column mass loading, but VA will dominate the scattering and optical depth.

Turning back to surface data, the ratio of the mean absorption coefficients $\left(\sigma_{\mathrm{ap}}\right)$ between AD and VA suggests that AD absorbs $50 \%$ more sunlight than what VA absorbs. To calculate the local heating rate after the absorption by VA or by

$\mathrm{AD}$ we combined the Beer's Lambert law for the absorption rate, $\frac{\mathrm{dF}}{\mathrm{dz}}=\frac{\sigma_{\mathrm{ap}}}{\mu} \mathrm{F}$ with the equation for the local heating rate, $\frac{\mathrm{dT}}{\mathrm{dt}}=\frac{1}{\mathrm{C}_{\mathrm{p}} \rho} \frac{\mathrm{dF}}{\mathrm{dZ}}$ and obtained, $\frac{\mathrm{dT}}{\mathrm{dt}}=\frac{\sigma_{\mathrm{ap}}}{\mu \mathrm{C}_{\mathrm{p}} \rho} \mathrm{F}$, where $F$ is the flux density at altitude $\mathrm{z} ; \frac{\mathrm{dF}}{\mathrm{dz}}$ is the absorption rate; $\mu$ is the cosine of the zenith angle; $\sigma_{\mathrm{ap}}$ is the absorption coefficient; $\mathrm{C}_{\mathrm{p}} \rho$ is the heat capacity of air $\left(1 \mathrm{~kJ} \mathrm{~K}^{-1} \mathrm{~kg}^{-1}\right)$ times $\rho$, the density of air; and dT/dt is the local heating rate. The equation for $\mathrm{dT} / \mathrm{dt}$ shows that the heating rate is directly proportional to the absorption coefficient. If we substitute the absorption coefficient for $\mathrm{AD}$ and for VA in the last equation, we get that the change in temperature because of $\mathrm{AD}$ is $50 \%$ greater than the change in temperature because of $\mathrm{VA}$. This result only considers the change in temperature because of absorption but omits the effect on temperature because of radiation cooling. An implication of this result is the need to measure the absorption coefficient accurately. To keep or improve this accuracy needs that we continue improving the techniques to measure absorption. In the next section, we will analyze the columnar optical depth, contrasting, or comparing it with the surface scattering.

\subsubsection{Columnar Aerosol Optical Depth}

Similar to the surface mean $\left(\sigma_{\mathrm{sp}}\right)$, the columnar mean $(\mathrm{AOD})$ for $\mathrm{AD}$ was greater than that of other aerosols categories.

For example, the mean AOD for AD was 5 times greater than that of $\mathrm{CM}$ and 3.5 times greater than that of CMS. In 

imply a greater AD fraction transported above, than within the MBL. Based on the SAL and on Reid et al. (2003a, b), African dust appears more often from the top of the MBL to the trade wind inversion up to $5000 \mathrm{~m}$. Hence, the greater $\mathrm{AD}$ fraction above is due to the SAL that is transporting a greater amount of mass above the MBL. For the VA, mean $\sigma_{\mathrm{sp}}$ was 1.1 times greater than that for the CMS and the columnar mean AOD for the VA was 1.6 times greater than that for the CMS. Therefore, the VA enhanced the optical depth more than the surface scattering if the VA superimposed on the CMS. Also, the VA enhanced the scattering and increased the optical depth by a factor of two. Furthermore, mean $\sigma_{\mathrm{sp}}$ for $\mathrm{AD}$ was 1.7 times greater than that for VA and mean AOD was 2.1 times greater. Therefore, within the MBL, $\mathrm{AD}$ increased the scattering $70 \%$ more than that by VA and doubled the columnar optical depth produced by VA.

\subsection{Intensive variables by aerosol category}

\subsubsection{Columnar Aerosol Optical Depth Fine Fraction (AODFF)}

Concerning particle sizes causing extinction in the atmospheric column, an overall mean AODFF of 0.27 implies that, on average, coarse particles caused three-fourths of the visible light extinction by aerosols. In addition, mean AODFF among aerosol categories was significantly different, except between CM and CMS. This result suggests that in Puerto Rico, different aerosol categories have significantly different columnar size distributions. For instance, the mean AODFF in VA was 0.09 more than mean AODFF in AD with a 95\% CI from 0.04-0.14. Hence, at $\mathrm{p}<0.05$, columnar VA were on average, significantly smaller than columnar $\mathrm{AD}$ and columnar marine aerosols. In other words, we are more than 95\% certain that columnar VA are smaller than columnar $\mathrm{AD}$ or marine aerosols. The mean AODFF in marine and $\mathrm{AD}$ aerosols differed significantly by $\sim 0.03$. These results support our hypothesis concerning aerosol sizes. Users of these data should decide if these differences, although statistically significant, are meaningful to them. Our results, in agreement with Reid et al. (2003b), show that coarse aerosols dominate the extinction of visible light in Puerto Rico.

\subsubsection{Scattering $\left(\mathbf{R}_{\mathrm{sp}}\right)$ and Absorption $\left(\mathbf{R}_{\mathrm{ap}}\right)$ Fractions}

Concerning the sizes of the scattering particles, mean sub-micron scattering fractions, $R_{\text {sp }}$, were on average low (Table 3 ), with a mean of 0.2 . Hence, coarse aerosols produced $80 \%$ of the scattering within the MBL. In addition, mean $\mathrm{R}_{\mathrm{sp}}$ for VA was significantly greater than mean $\mathrm{R}_{\mathrm{sp}}$ for $\mathrm{AD}$. Even though they only differed by 0.03 with a $95 \% \mathrm{CI}$ from 0.01 to 0.05 , the result means that we are more than $95 \%$ certain that, within the MBL, volcanic ash has a smaller fraction of coarse scattering particles than what $\mathrm{AD}$ and marine aerosols have. The lowest mean $\mathrm{R}_{\mathrm{sp}}$ in marine aerosols implies that marine aerosols have the greatest fraction (> 85\%) of coarse aerosols. Therefore, the scattering particles sizes among natural aerosols in Puerto Rico were significantly different, supporting our hypothesis.

The overall mean $\mathrm{R}_{\mathrm{ap}}$ of $\sim 0.5$ showed that on average, the amount of coarse/fine absorbing aerosols in Puerto Rico, is similar within the MBL. The smaller mean $\mathrm{R}_{\mathrm{ap}}(0.37)$ for $\mathrm{AD}$ contrasts with the mean $\mathrm{R}_{\mathrm{ap}}$, otherwise, that only differed few hundredths from a mean of 0.6. Hence, coarse absorbing particles in AD produced $63 \%$ of the absorption. Therefore, if the absorption by fine $\mathrm{AD}$ particles was due to soot, or the $\mathrm{AD}$ fine mode, or a mix of these two, the result implies that absorption by the coarse iron oxides surpassed the absorption by the fine. A question arising is: Why are absorbing aerosols smaller in VA than in AD if both are iron oxides? One explanation is that VA are generated by a mechanism in which aerosols are heated to elevated temperatures. These results also show that coarse aerosols produced most of the 
Atmos. Chem. Phys. Discuss., https://doi.org/10.5194/acp-2018-791 coarse aerosols to move from the Sahara to the Caribbean and farther to Miami (Prospero, 1999), after their lift to high altitudes. Our methods to segregate the sub-micron particles from the total allowed us to measure what fraction of the total scattering and absorption was due to sub-micron aerosols.

A surface mean $\mathrm{R}_{\mathrm{sp}}$ of 0.2 and a columnar mean AODFF of 0.27 agree that coarse aerosols produced most of the scattering within the MBL and most of the columnar extinction in Puerto Rico. But the overall mean $\mathrm{R}_{\mathrm{sp}}$ was $35 \%$ smaller than the columnar mean AODFF, implying that the size distributions at the surface vs. column average are a major contribution to this difference. Another contributor is the difference in the sizes separating the columnar fine/coarse AOD and surface submicron/super-micron scattering or absorption. The size cut for surface data is $1 \mathrm{~m}$ aerodynamic diameter corresponding to $0.7 \mu \mathrm{m}$ geometric diameter for a particle density of 2.0. The AERONET "size cut" is poorly defined but is larger than $0.7 \mu \mathrm{m}$ geometric diameter. Also, the difference in relative humidity aloft vs. at the surface may have to do with the difference between $\mathrm{R}_{\mathrm{sp}}$ and the AODFF. The nonsignificant difference between the measured $\mathrm{AOD}$ at $500 \mathrm{~nm}$ and the interpolated $\mathrm{AOD}$ to $550 \mathrm{~nm}$ suggests that comparing/contrasting $\sigma_{\mathrm{sp}}$ at $550 \mathrm{~nm}$ and AOD at $500 \mathrm{~nm}$ have a similar difference as comparing/contrasting them at the same wavelength $(550 \mathrm{~nm})$.

\subsubsection{Single Scattering Albedo $\left(\omega_{0}\right)$}

The difference between mean $\omega_{0}$ for $\mathrm{AD}$ and for VA was nonsignificant, even though the values of $\sigma_{\mathrm{sp}}$ and $\sigma_{\mathrm{ap}}$ to derive $\omega_{0}$, were significantly greater for $\mathrm{AD}$. Also, the absorbing particles were significantly larger for $\mathrm{AD}$ than the absorbing particles for VA. The mean $\omega_{0}$ for marine aerosols was $\sim 0.99$. We calculated the uncertainty in $\sigma_{\text {ap }}$ associated with the calibration constants in Eqn. (1) $\left(\sigma_{\text {meas }}=K_{1} \sigma_{\mathrm{sp}}+K_{2} \sigma_{\mathrm{ap}}\right)$ of Bond et al. (1999), including the adjustment by Ogren (2010), with $\sigma_{\text {meas, }}$ the apparent absorption. In this adjustment, $K_{2}=1.44 \pm 0.24$ and $K_{1}=0.02 \pm 0.02$ such as in Bond et al. (1999). With $a$ defined as $a=\frac{\omega_{0}}{1-\omega_{0}}=\frac{\sigma_{\mathrm{sp}}}{\sigma_{\mathrm{ap}}}$ and the relative uncertainty as $\frac{\sigma_{a p, c a l}}{\sigma_{a p}}=\frac{\left(\left(a * \Delta K_{1}\right)^{2}+\left(\Delta K_{2}\right)^{2}\right)^{1 / 2}}{\left(a * K_{1}+K_{2}\right)^{2}}$, Eqn. (S4c) in Sherman et al. (2015) becomes, $\frac{\sigma_{a p, c a l}}{\sigma_{a p}}=\frac{\left(\left(0.02 * \frac{\omega_{0}}{1-\omega_{0}}\right)^{2}+(0.24)^{2}\right)^{1 / 2}}{\left(0.02 * \frac{\omega_{0}}{1-\omega_{0}}+1.44\right)^{2}}=17 \%$ relative uncertainty for marine aerosols. The term $\sigma_{\text {ap,cal }}$ is the uncertainty in $\sigma_{\text {ap }}$ resulting from uncertainties in the calibration constants and $\sigma_{\text {ap }}$ is the absorption coefficient. Mean $\omega_{0}$ was 0.96 for $\mathrm{AD}$ and for VA, with a relative uncertainty of $15 \%$. The uncertainty in $\sigma_{\text {meas }}$ also contributes to the total uncertainty of $\Delta \sigma_{\mathrm{ap}} / \sigma_{\mathrm{ap}}$ and $\Delta \omega_{0} / \omega_{0}$. Uncertainties greater than 0.01 in $\Delta \omega_{0} / \omega_{0}$ would yield an $\omega_{0}$ greater than one, which is physically impossible. From these results, the marine aerosols absorption coefficient could be zero. If the $95 \% \mathrm{CI}$ for $\omega_{0}$ includes values greater than 1.0 , we cannot reject the hypothesis that marine aerosols are nonabsorbing. Even though values of $\omega_{0}$ above 1.0 are physically impossible, the measurement techniques, which are difference-based, means that measured values above 1.0 are possible. To analyze whether $\omega_{0}$ depends on å, we plotted $\omega_{0}$ vs. å in Figure 7 that shows a weak correlation, which may have to do with absorbing particles sizes not only in the fine mode but also in the coarse mode. Also, results for $\mathrm{R}_{\mathrm{ap}}$ showed that coarse $\mathrm{AD}$ aerosols had greatest absorption coefficient. Smaller $\omega_{0}$ and å in Figure 7 suggests absorption by coarse aerosols such as the iron oxides in AD (Moosmüller et al. (2009). Our results for $\omega_{0}$ in AD (0.96) support the findings by E. A. Reid (2003) that elemental iron composes $\sim 2.5-3 \%$ of the total dust mass. 


\subsubsection{Radiative Forcing Efficiency ( $\Delta R F / A O D)$}

The mean radiative forcing efficiency $(\triangle \mathrm{RF} / \mathrm{AOD})$ was significantly different among aerosol categories. For instance, mean $\triangle \mathrm{RF} / \mathrm{AOD}$ for $\mathrm{AD}$ was greater (about $2 \mathrm{~W} \mathrm{~m}^{-2}$ ) than that of $\mathrm{CM}$, and $\sim 1 \mathrm{~W} \mathrm{~m}^{-2}$ greater than those of CMS and VA. To compare the radiative cooling because of $\mathrm{AD}$ and because of VA, we first calculated the average of $\triangle \mathrm{RF} / \mathrm{AOD}$ and AOD for the period and then found the product of the two averages for $\mathrm{AD}$ and for VA. We obtained a mean radiative cooling of $-11.7 \mathrm{~W} \mathrm{~m}^{-2}$ for $\mathrm{AD}$ and $-5.7 \mathrm{~W} \mathrm{~m}^{-2}$ for $\mathrm{VA}$. Equivalently, $\mathrm{AD}$ produced around twice the cooling of VA at the top of the atmosphere, despite that $\mathrm{AD}$ produced a greater local heating rate due to absorption. Examining how $\triangle \mathrm{RF} / \mathrm{AOD}$ varies with the aerosol load, we plotted $\triangle \mathrm{RF} / \mathrm{AOD}$ vs. $\sigma_{\mathrm{sp}}$ (Figure 8a). Figure 8a shows that $\Delta \mathrm{RF} / \mathrm{AOD}$ varies more over the first $5-45 \mathrm{Mm}^{-1}$. In section 3.3.1 we found a log-normal distribution for $\sigma_{\mathrm{sp}}$. Therefore, one explanation for the large variability of $\triangle \mathrm{RF} / \mathrm{AOD}$ is that the log-normal, skewed to the right distribution of $\sigma_{\mathrm{sp}}$, creates a non-linear relation between $\sigma_{\mathrm{sp}}$ and $\Delta \mathrm{RF} / \mathrm{AOD}$. To make the relation linear, we transformed $\sigma_{\mathrm{sp}}$ in $\log \left(\sigma_{\mathrm{sp}}\right)$, where $\log \left(\sigma_{\mathrm{sp}}\right)$ is the natural logarithm of $\sigma_{\mathrm{sp}}$. Figure $8 \mathrm{~b}$ shows a linear-log regression model of the form, $\frac{\Delta \mathrm{RF}}{\mathrm{AOD}}=\alpha+\beta \log \sigma_{\mathrm{sp}}$ with $\alpha=-30.7 \mathrm{~W} \mathrm{~m}^{-2}$ being the intercept on the vertical axis and $\beta=1.15$, the slope of the line. The model predicts that an increase of $\log \sigma_{\mathrm{sp}}$ by one unit, changes $\triangle \mathrm{RF} / \mathrm{AOD}$ by 1.15 . Substituting the smallest measured scattering coefficient $\sigma_{\mathrm{sp}}$ of around $10 \mathrm{Mm}^{-1}$ in the regression model gives $\frac{\Delta \mathrm{RF}}{\mathrm{AOD}} \sim-28 \mathrm{~W} \mathrm{~m}^{-2}$. An increase of $20 \%$ in $\sigma_{\mathrm{sp}}=10 \mathrm{Mm}^{-1}$ would result in $\frac{\Delta \mathrm{RF}}{\mathrm{AOD}}=-30.7 \mathrm{~W} \mathrm{~m}^{-2}+1.15 \log (1.2 * 10) \mathrm{W} \mathrm{m}^{-2}=-28 \mathrm{~W} \mathrm{~m}^{-2}+0.21 \mathrm{~W} \mathrm{~m}^{-2}$. Therefore, an increase of $20 \%$ in $\sigma_{\mathrm{sp}}$ would result in $0.21 \mathrm{~W} \mathrm{~m}^{-2}$ increase of $\triangle \mathrm{RF} / \mathrm{AOD}$. We thus showed that greater loadings of $\mathrm{AD}$ aerosols caused greater radiational cooling at the top of the atmosphere and greatest local heating within the MBL and that $\triangle \mathrm{RF} / \mathrm{AOD}$ depends on the aerosol loading. We also estimated the increase in $\triangle \mathrm{RF} / \mathrm{AOD}$ as $\sigma_{\mathrm{sp}}$ increase by a certain percent. From Table 3 we can determine the relative frequency of each aerosol category and how much each category contributes to $\triangle \mathrm{RF} / \mathrm{AOD}$ over Puerto Rico: AD contributes 58\%, CM plus CMS 27\%, and VA 15\%.

Eqn. 6 shows that $\triangle \mathrm{RF} / \mathrm{AOD}$ also depends on two aerosol properties, single-scattering albedo $\left(\omega_{0}\right)$ and upscatter fraction ( $\beta$ ). To diagnose the overall relation in Figure 8a, we plotted the relation between $\triangle R F / A O D$ and these two aerosol variables separately (Figure 9 and Figure 10). The results show a clear dependence of $\triangle R F / A O D$ on the upscatter fraction, illustrating the importance of knowing the backscatter fraction to calculate it and the importance of the aerosols' sizes. A clear dependence of $\triangle \mathrm{RF} / \mathrm{AOD}$ on $\omega_{0}$ is not seen in Figure 10. This is due to the fact that, in Puerto Rico, there is not enough variability in $\omega_{0}$. Summarizing, we found that besides the effects of the upscatter fraction and the single scattering albedo, the aerosol loading accounted for around 50\% of the change in the radiative forcing efficiency.

\subsection{Monthly climatology}

Note that mean $\sigma_{\mathrm{sp}}$ and AOD peaks in summer because of $\mathrm{AD}$ (Figure 11 (a) and (b)). The monthly variation of $\sigma_{\mathrm{sp}}$ peaks in June and the mean variation of AOD peaks in July. Two explanations for the difference in timing of the maxima are: 1) we recorded $\sigma_{\mathrm{sp}}$ at controlled RH and the AERONET assessed AOD at ambient RH and 2), the transport aloft brings different amounts of aerosols than the transport in the MBL. The result is consistent with Reid et al. (2002) that reported highest dust concentrations in the MBL in June. The climatology of $\sigma_{\mathrm{sp}}$ and AOD also agrees with Prospero (1999) that the seasonality for AD peaks in summer.

Mean $\sigma_{a p}$ was smaller in July than in other months (Figure 12) implying that most of the absorbing aerosols are above the MBL as suggested by the greatest columnar AOD. The maximum $\sigma_{\mathrm{ap}}$ in May 8, 2008 was due to an AD event. 
Because on May 7, 2008 we sensed VA at CPR and $\sigma_{a p}$ is extensive and additive, this high value may have to do with $\mathrm{VA}$, although VA, if any, was underneath the AD. The absorption increased from $0.8 \mathrm{Mm}^{-1}$ on May 6 , to $6 \mathrm{Mm}^{-1}$ on May 7 and $10.8 \mathrm{Mm}^{-1}$ on May 8. The corresponding $\sigma_{\mathrm{sp}}$ increased from 65 to 165 to $219 \mathrm{Mm}^{-1}$ for the same days. The maximum $\sigma_{\text {ap }}$ in May 8, 2008 could be due to the $\sigma_{\text {ap }}$ of AD added to the $\sigma_{\text {ap }}$ of VA because $\sigma_{\text {ap }}$ is extensive and extensive properties are additive.

Black carbon (BC) from forest fires in Brazil may have to do with the greater mean $\sigma_{\mathrm{ap}}$ in September and October. We base this statement on the trajectories, forest fires in Brazil, and the southern long-range transport due to cyclones over the Atlantic. Absorption of 6 to $7 \mathrm{Mm}^{-1}$ had corresponding $\sigma_{\mathrm{sp}}$ of 35 to $37 \mathrm{Mm}^{-1}$. Hence, greater absorption in September and October may have to do with BC from the forest fires in SA. We saw this transport three days in October, and two days in September.

The low mean $R_{\mathrm{sp}}$ in Figure 13 (a) shows a small variation through the year, suggesting that coarse marine aerosols are always present in Puerto Rico. The lower monthly mean $\mathrm{R}_{\mathrm{sp}}$ in June and in July suggests more coarse AD aerosols arriving to the MBL enhancing the coarse marine aerosols. From March to May, and in September and October, a greater mean $R_{s p}$ suggests a smaller fraction of coarse particles. The $R_{s p}$ monthly variation at the surface resembles the monthly variation of the columnar AODFF (Figures 13 (a) and (b)). Namely, smaller mean $R_{s p}$ and AODFF in July, suggest more coarse mode scattering particles within the MBL and columnar, in July. Due to the continuous release of coarse sea-salt particles at the surface, the mean monthly $R_{\mathrm{sp}}$ was lower than that of AODFF through the year. The two parameters have low values showing that coarse aerosols (such as marine) dominated the scattering of within the MBL and extinction in the atmospheric column. The AD coarse mode enhanced the marine coarse mode in summer as shown by the lower values $R_{\mathrm{sp}}$ and AODFF.

Absorbing particles were mostly sub-micron from January to May and in December (Figure 14). Even though the dust season peaks in summer, the easterlies shape the local weather until November, suggesting that coarse AD aerosols dominated and caused a low mean $\mathrm{R}_{\mathrm{ap}}$ from June to November within the MBL. This result agrees with Prospero et al. (1970) and Prospero and Carlson (1972) that synoptic outbreaks of Saharan dust occur from late spring to fall. Volcanic ash caused the greatest mean $R_{a p}$ of around 0.7 and a maximum $R_{a p}$ of 0.95 on March 24, 2008.

Figure 15 (a) shows the monthly climatology of $\omega_{0}$. We have noted that September had the smallest mean $\omega_{0}$ and the median $\omega_{0}$ throughout the year stayed greater than 0.96. December, January, February, and March had mean monthly $\omega_{0}$ of $\sim 0.97$. This result implies that marine aerosols are always present and are thus important for the radiative balance. The lowest mean $\omega_{0}$ occurred in September with a mean of 0.95 and minimum about 0.90 . The monthly variability of the radiative forcing efficiency $(\triangle \mathrm{RF} / \mathrm{AOD}$ ) throughout the year was greater in March, in April, and in May (Figure 15 (b)). The variability in the mean $\triangle \mathrm{RF} / \mathrm{AOD}$ was small through from $2006-2010$. The larger range in these months may be due to the collective effects of the fine, absorbing particles of volcanic ash and the coarse, less absorbing marine aerosol. Monthly means, however, varied little $\left(27 \pm 1 \mathrm{~W} \mathrm{~m}^{-2}\right)$.

\section{Conclusions}

40

We have analyzed the means and variability of the radiative-forcing properties of natural aerosols in Puerto Rico, and we have suggested several criteria to classify them according to their source. Mean loads, sizes, and absorbing properties 
Atmos. Chem. Phys. Discuss., https://doi.org/10.5194/acp-2018-791

Manuscript under review for journal Atmos. Chem. Phys.

Discussion started: 7 August 2018

(c) Author(s) 2018. CC BY 4.0 License.

Atmospheric

Chemistry

and Physics

Discussions

(c) (i)

were different among aerosols in Puerto Rico at $\mathrm{p}<0.05$. The radiative forcing properties were different not only within the MBL, but also in the atmospheric column. Therefore, we accepted our hypothesis for the parameters associated with the loads and with the sizes at the surface and columnar. We rejected the hypothesis for differences in the single scattering albedo between African dust and volcanic ash. However, the parameters computed with the single scattering albedo and the parameters used to compute the single scattering albedo were different.

The absorbing particles in African dust were larger than the absorbing particles in volcanic ash. Even though smaller sizes as in volcanic ash have greater scattering efficiency, African dust produced a greater radiative cooling at the top of the atmosphere due to it greater load. African dust could produce a local heating rate $50 \%$ greater than that of volcanic ash because of greater absorption coefficient. However, we could not distinguish among aerosols of distinct categories only knowing their means and variability because their frequency distributions overlap much.

Despite the uncertainty, our method to classify aerosols can, on average, contribute to understand the means and the variability in the radiative-forcing properties. Agreement between our results and the empirical evidence cited from earlier studies allow us to conclude that our classification method is feasible. We also presented the monthly climatology of aerosols radiative-forcing properties in Puerto Rico. Size-resolved measurements showed that the coarse mode dominated the scattering and absorption in African dust. Coarse marine aerosols dominated the volume (and mass) because they are near the source at the surface, despite falling faster than $\mathrm{AD}$ aerosols with a smaller size mode. Trajectories (Table 1) showed that AD aerosols last 5-7 days to reach CPR. The continuous production at the surface makes marine aerosols important because they are a continuous source of scattering. Continuing efforts to measure or estimate upscatter fraction, such as in Andrews et al. (2006) to estimate the asymmetry factor, would help to decrease the uncertainty in calculated radiative forcing efficiency, this is because our results showed that variations in upscatter fraction strongly contribute to variations in radiative forcing efficiency. Because different absorbing aerosols cause different changes in temperature, the accurate measurement of absorption continues as one key issue in the study of the climate-forcing properties of aerosols.

In this work the PSAP values were adjusted to $550 \mathrm{~nm}$, but we have used the AOD values measured at $500 \mathrm{~nm}$. We have done some interpolations to analyze the data at $550 \mathrm{~nm}$. Our preliminary results indicate that the AOD values interpolated to $550 \mathrm{~nm}$ are not significantly different from the measured values at $500 \mathrm{~nm}$. Therefore, we believe that the use of the values at $500 \mathrm{~nm}$ fall within the scope of the present work. Nonetheless it remains our intention to take up the case of AOD values adjusted at $550 \mathrm{~nm}$ in more details in further work in the near future. 
Atmos. Chem. Phys. Discuss., https://doi.org/10.5194/acp-2018-791

Manuscript under review for journal Atmos. Chem. Phys.

Discussion started: 7 August 2018

(c) Author(s) 2018. CC BY 4.0 License.

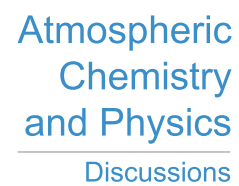

(c) (1)

Discussions

Acknowledgements. We gratefully acknowledge Patrick Sheridan (NOAA), and Anne Jefferson and Derek Hageman (University of Colorado) for their contributions to station operations and data processing, as well as the NOAA Climate Program Office for the funding support. We also acknowledge the NSF AGS 0936879 and the NSF GK-12 Scholarship for their financial support, and the Conservation Trust of Puerto Rico for the use of their facilities at the nature reserve 5 of Cabezas de San Juan. (CSJ). Thanks to the Atmospheric Chemistry and Aerosols Research Group at UPR-RP for their support (especially to Mr. Félix Zürcher, Ian Gutiérrez and Carmelo Costacamps). We thank Gerardo Morell for his financial support through NASA EPSCOR and José F. Nieves for their financial support through Department of Physics PEAFs. 


\section{References}

Anderson, T., and Ogren J. A.: Determining Aerosol Properties Using the TSI 3563 Integrating Nephelometer, Aero. Sci. Tech., 29, 57-69, 1998.

Andrews, E., Sheridan, P. J., Fiebig, M., McComiskey, A., Ogren, J. A., Arnott, P., Covert, D., Elleman, R., Gasparini, R., Collins, D., Jonsson, H., Schmid, B., and Wang, J.: Comparison of methods for deriving aerosol asymmetry parameter, J. Geophys. Res.,111, 05S04, doi:10.1029/2004JD005734.

Baxter, P. J., Bonadonna, C., Dupree, R., Hards, V. L., Kohn, S. C., Murphy, M. D., Nichols, A., Nicholson, R. A., Norton, G., Searl, A., Sparks, R. S., and Vickers, B. P.: Cristobalite in volcanic ash of the Soufrière Hills volcano, Montserrat, British West Indies, Science, 283, 1142-1145, 1999.

Blanchard, D. C. and Woodcock, A. H.: Production, concentration, and vertical distribution of the sea salt aerosols. Ann. N. Y. Acad. Sci 353, 186-200, 1980.

Bohren, C. F. and Huffman, D. R.: Absorption and Scattering of Light by Small Particles, John Wiley, Hoboken, N. J, 1983. Bond, T. C., Anderson, T. L. and Campbell, D.: Calibration and intercomparison of filter-based measurements of visible light absorption by aerosols. Aerosol Sci. Technol., 30, 582-600, 1999.

Bonadonna, C., Macedonio, G., and R.S. Sparks, R. S.: Numerical modelling of tephra fallout associated with dome collapses and Vulcanian explosions: application to hazard assessment on Montserrat, in: The eruption of Soufriere Hills Volcano, Montserrat, from 1995 to 1999, edited by: Druitt, T. H. and Kokelaar, B. P., Geological Society, London, Memoir, 517-537, 2002.

Bonadonna, C., Connor, C., Houghton, B. F., Connor, L., Byrne, M., Laing, A., and Hincks, T. K.: Probabilistic modeling of tephra dispersal: Hazard assessment of a multiphase rhyolitic eruption at Tarawera, New Zealand. $J$. Geophys. Res. 110, B03203, doi: 10.1029/2003JB002896, 2005.

Burton, S. P., Hair, J. W., Kahnert, M., Ferrare, R. A., Hostetler, C. A., Cook, A. L., Harper, D. B., Berkoff, T. A., Seaman, S. T., Collins, J. E., Fenn, M. A., and Rogers, R. R.: Observations of the spectral dependence of linear particle depolarization ratio of aerosols using NASA Langley airborne High Spectral Resolution Lidar, Atmos. Chem. Phys., 15, 13453-13473, doi:10.5194/acp-15-13453-2015, 2015.

Charlson, R. J., Langner, J., Rodhe, H., Leovy, C. B., and S.G. Warren, S. G.: Perturbation of the Northern Hemisphere Radiative Balance by Backscattering from Anthropogenic Sulfate Aerosols, Tellus 43AB (4):152-163, 1991.

Delene, D. J. and Ogren, J. A.: Variability of Aerosol Optical Properties at Four North American Surface Monitoring Sites, J. Atmos. Sci., 59, 1135-1150, 2002.

Denjean, C., Formenti, P., Desboeufs, K, Chevaillier, S., Triquet, S., Maillé, M., Cazaunau, M., Laurent, B., MayolBracero, O. L., Vallejo, P., Quiñones, M., Gutierrez, I., Cassola, F., Prati, P., Ogren, J. A., and Andrews, E.: Size distribution and optical properties of African mineral dust after intercontinental transport, J. Geophys. Res. Atmos., 121, 7117-7138, doi:10.1002/2016JD024783, 2016.

Draxler, R. R. and Hess G. D.: An overview of the HYSPLIT_4 modelling system for trajectories, dispersion and deposition, Aust. Met. Mag., 47, 295-308, 1998.

Draxler, R. R. and Rolph, G. D.: HYSPLIT (HYbrid Single-Particle Lagrangian Integrated Trajectory) Model access via NOAA ARL READY Website (http://ready.arl.noaa.gov/HYSPLIT.php). NOAA Air Resources Laboratory, Silver Spring, MD, 2013.

40 Dubovik, O. and King, M. D.: A flexible inversion algorithm for retrieval of aerosols optical properties from sun and sky radiance measurements, J. Geophys. Res., 105, D16, 20673, 2000. 
Atmos. Chem. Phys. Discuss., https://doi.org/10.5194/acp-2018-791

Haywood, J. M. and Shine, K. P.: The effect of anthropogenic sulphate and soot aerosol on the clear sky planetary radiation budget, Geophys. Res. Lett. 22, 603-606, 1995.

Holben, B. N., Eck, T. F., Slutsker, I., Tanre, D., Buis, J. P., Setzer, A., Vermote, E., Reagan, J. A., Kaufman, Y. J., Nakajima, T., Lavenu, F., Jankowiak, F., and Smirnov, A.: AERONET - A federated instrument network and data archive for aerosol characterization, Remote Sens. Environ., 66, 1-16, 1998.

Holben, B. N., Eck, T. F., Slutsker, I., Smirnov, A., Sinyuk, A., Schafer, J., Giles, D., and Dubovik, O.: AERONET's Version 2.0 quality assurance criteria, in Remote Sensing of the Atmosphere and Clouds, edited by S.-C. Tsay et al., Proc. SPIE, 6408, 64080Q, doi: 10.1117/12.706524, 2006.

Houghton, J. T., Ding, Y., Griggs, D. J., Noguer, M., Van der Linden, P. J., Dai, X., Maskell, K, and Johnson, C. A.: Climate Change 2001, The Scientific Basis, Cambridge Univ. Press, Cambridge, U.K., 2001.

Housley, D., Bérubé, K. A., Jones, T. P., Anderson, S., Pooley, F. D., and Richards, R. J.: Pulmonary epithelial response in the rat lung to instilled Montserrat respirable dusts and their major mineral components, Occup. Environ. Med., 59, 466-472, 2002.

Huneeus, N., Schulz, M., Balkanski, Y., Griesfeller, J., Kinne, S., Prospero, J., Bauer, S., Boucher, O., Chin, M., Dentener, M. F., Diehl, T., Easter, R., D. Fillmore, D., Ghan, S., Ginoux, P., Grini, A., Horowitz, L., Koch, D., Krol, M. C., Landing, W, Liu, X., Mahowald, N., Miller, R. L., Morcrette, J., G. Myhre, G., J.E. Penner, J. E., Perlwitz, J. P., Stier, P., Takemura, T., and C. Zender, C.: Global dust model intercomparison in AeroCom phase I. Atmos. Chem. Phys., 11, 7781-7816, doi:10.5194/acp-11-7781, 2011.

IPCC: Climate Change 2001: The Scientific Basis. In: Contribution of Working Group I to the Third Assessment Report of the Intergovernmental Panel on Climate Change (eds Houghton, J. T., Ding, Y., D. J. Griggs, D. J., Noguer, M., and van der Linden, P. J., 2001.

IPCC: Climate Change 2013: The Physical Science Basis. Contribution of Working Group I to the Fifth Assessment Report of the Intergovernmental Panel on Climate Change, Stocker, T. F., Qin, D, Plattner, G. K., Tignor, M., Allen,

S. K., Boschung, J., Nauels, A., Xia, Y., Bex, V., and Midgley, P. M., (eds.).: Cambridge University Press,

Cambridge, United Kingdom and New York, NY, USA, 2013.

Jacobson, M. Z.: Strong radiative heating due to the mixing state of black carbon in atmospheric aerosols, Nature, 409, 695697, 2001.

Karyampudi, V. M. and Carlson, T. N.: Analysis and numerical simulations of the Saharan Air Layer and its effect on easterly wave disturbances. J. Atmos. Sci., 45, 3102-3136, 1988.

Kleefeld, S, Hoffer, A, Krivácsy, Z, and Jennings, S.G.: Importance of organic and black carbon in atmospheric aerosols at Mace Head, on the west coast of Ireland (53 $\left.{ }^{\circ} 19^{\prime} \mathrm{N}, 9^{\circ} 54^{\prime} \mathrm{W}\right)$. Atmospheric Environment 36:4479-90, 2002. Kokhanovsky, A. A.: Aerosol Optics, Light Absorption and Scattering by Particles in the Atmosphere, 1st ed., 1, 1-15, Berlin, Heidelberg: Praxis Publishing Ltd, 2008. 
Lewis, E. R. and Schwartz, S. E.: Sea Salt Aerosol Production: Mechanisms, Methods, Measurements, and Models -

5 A Critical Review, Geophysical monograph 152, American Geophysical Union, Washington, DC, 413 pp., 2004.

Liao, H. and Seinfeld, J. H.: Effect of Clouds on Direct Aerosol Radiative Forcing of Climate, J. Geophys. Res., 103, 37813788, 1998.

Li-Jones, X. and Prospero, J. M.: Variations in the size distributions of non-sea-salt sulfate aerosol in the marine boundary layer at Barbados: Impact of African dust, J. Geophys. Res. 103, 16073-16084, 1998.

10 Lovett, R. F.: Quantitative measurement of airborne sea-salt in the North Atlantic, Tellus, 30, 358-363, 1978. Mather, T. A., D. M. Pyle, and C. Oppenheimer.: Tropospheric volcanic aerosol. In Volcanism and The Earth's Atmosphere, A. Robock and C. Oppenheimer, Eds., Geophysical Monograph 139 (American Geophysical Union, Washington, DC), 189-212, 2003.

Moore, K. R., Duffel, H., Nicholl A., and Searl A.: Monitoring of airborne particulate matter during the eruption of Soufrière Hills volcano, Montserrat, in the eruption of Soufrière Hills Volcano, Montserrat, from 1995 to 1998, edited by T. H. Druitt and B. P. Kokelaar, Geol. Soc. Lond. Memoirs, 21, 557-566, 2002.

Moosmüller, H., Chakrabarty, R. K., and Arnott, W. P.: Aerosol Light Absorption and its Measurement: A Review, J. Quant. Spectrosc. Ra., 110, 844-878, 2009.

O’Dowd, C. D., and Smith M. H.: Physicochemical properties of aerosols over the Northeast Atlantic: Evidence for windspeed-related submicron sea-salt aerosol production, J. Geophys. Res., doi: 10.1029/92JD02302,1137-1149, 1993.

O’Dowd, C. D., Facchini, M. C., Cavalli F., Ceburnis, D., Mircea, M., Decesari, S., Fuzzi, S., Yoon, Y. J., and Putaud, J.: Biogenically driven organic contribution to marine aerosol, Nature, 431, 676-680, doi: 10.1038/nature02959., 2004.

25 Ogren, J. A.: In situ observations of aerosol properties, in Aerosol Forcing of Climate, edited by R. J. Charlson and J. Heintzenberg, pp. 215-226, John Wiley, Hoboken, N. J., 1995.

Ogren, J. A.: Comment on "Calibration and Intercomparison of filter-based measurements of visible light absorption by aerosols. Aerosol Sci. and Technol., 44, 589-591, 2010.

O'Neill, N. T., Dubovik, O., and Eck, T. F.: A modified Angstrom coefficient for the characterization of sub-micron aerosols, App. Opt., Vol. 40, No. 15, pp. 2368-2374, 2001.

O'Neill, N. T., Eck, T. F., A. Smirnov, A., B. Holben, and N. Thulasiraman, S.: Spectral discrimination of coarse and fine mode optical depth, Vol., 108, J. Geophys. Res., No. D17, 4559-4573, 10.1029/2002JD002975, 2003.

Prospero, J. M., Bonatti, E., Schubert, C., and Carlson, T. N.: Dust in the Caribbean atmosphere traced to an African dust storm, Earth Planet. Sci. Lett., 9, 287-293, 1970.

Prospero, J. and Carlson, T.: Vertical and areal distribution of Saharan dust over the western equatorial North Atlantic Ocean, J. Geophys. Res., 77, 5255-5265, doi: 10.1029/JC077i027p05255, 1972.

Prospero, J.: Long-Term measurements of the transport of African mineral dust to the south-eastern United States: Implications for regional air quality, J. Geophys. Res., 104, 15917-15927, 1999.

Prospero, J. M. and Mayol-Bracero, O. L.: Understanding the Transport and Impact of African Dust on the Caribbean 
Atmos. Chem. Phys. Discuss., https://doi.org/10.5194/acp-2018-791

Reid, J. S., Westphal, D. L., Livingston, J. M., Savoie, D. L., Maring, H. B. Jonsson, H. H., Eleuterio, D. P., Kinney, J.

E., and Reid, E. A.: Dust vertical distribution in the Caribbean during the Puerto Rico Dust Experiment, Geophys. Res. Lett., 10 29(7), 1151, doi:10.1029/2001GL014092, 2002.

Reid, E. A., Reid, J. S., Broumas, A. P., Cliff, S. S., Meyer, M. M., Dunlop, M., Cliff, S. S., Broumas, A., Perry, K. D., and Maring, H.: Characterization of African dust transported to Puerto Rico by individual particle and size segregated bulk analysis, J. Geophys. Res., 108(D19), 8591, 2003.

Reid, J. S., Jonsson, H. H., Maring, H. B., Smirnov, A., Savoie, D. L., Cliff, S. S., Reid, E. A., Livingston, J. M., Meier, M. M., Dubovik, O., and Tsay S. C.: Comparison of size and morphological measurements of coarse mode dust particles from Africa, J. Geophys. Res., 108, D19, 8593, doi: 10.1029/2002JD002485, 2003b.

Reid, J. S., Kinney, J. E., Westphal, D. L., Holben, B. N., Welton, E. J., Tsay, S. C., Eleuterio, D. P., Campbell, J. R., Christopher, A., Colarco, P. R., Jonsson, H. H., Livingston, J. M., Maring, H. B., Meier, M. L., Pilewskie, P.,

Prospero, J. M., Reid, E. A., Remer, L. A., Russell, P. B., Savoie, D. L., Smirnov, A., and Tanre', D.: Analysis of measurements of Saharan dust by airborne and ground-based remote sensing methods during the Puerto Rico Dust Experiment (PRIDE), J. Geophys. Res., 58, D19, 8586, doi: 10.1029/2002JD002493, 2003a.

Seinfeld, J. H., and Pandis S. N.: Atmospheric Chemistry and Physics: from Air Pollution to Climate Change, Wiley, New York, 1998.

Sheridan, P. J. and Ogren, J. A.: Observations of the vertical and regional variability of aerosol optical properties over central and eastern North America. J. Geophys. Res., 104, 16 793-16 805, 1999.

Sherman, J. P., Sheridan, P. J., Ogren, J. A., Andrews, E., Hageman, D., Schmeisser, L., Jefferson, A. and Sharma, S.: A multi-year study of lower tropospheric aerosol variability and systematic relationships from four North American regions, Atmos. Chem. Phys., 15, 12487-12517, doi:10.5194/acp-15-12487, 2015.

Smirnov, A., Holben, B. N., Eck, T. F., Dubovik, O., and Slutsker, I.: Effect of wind speed on columnar aerosol optical properties at Midway Island, J. Geophys. Res., 108, 4802, doi:10.1029/2003JD003879, 2003.

Sokolik, I. N. and Toon, O. B.: Incorporation of mineralogical composition into models of the radiative properties of mineral aerosols from UV to IR wavelengths, J. Geophys. Res., 104, 9423-9444, 1999.

Sokolik, I., Winker, D. M., Bergametti, G., Gillettce, D., Carmichael, G., Kaufman, Y. J., Gomes, L., Schuetz, L., and

Penner, J. E.: Introduction to special section: Outstanding problems in quantifying the radiative impacts of mineral dust, J. Geophys. Res., 106, D16, 18015-18028, 2001.

Spiegel, J. K., Buchmann, N., Mayol-Bracero, O. L., Cuadra-Rodríguez, L. A., Valle-Díaz, C. J., Prather, K. A., Mertes, S. and Eugster, W.: Do Cloud Properties in a Puerto Rican Tropical Montane Cloud Forest Depend on Occurrence of Long range Transported African Dust? Pure Appl. Geophys. 171: 2443-2459, 2013. 
Atmos. Chem. Phys. Discuss., https://doi.org/10.5194/acp-2018-791

Manuscript under review for journal Atmos. Chem. Phys.

Discussion started: 7 August 2018

(c) Author(s) 2018. CC BY 4.0 License.

(c) (i)

Valle-Díaz, C. J., Torres-Delgado, E., Colón-Santos, S. M., T. Lee, T., J.L. Collett Jr., J. L., McDowell, W. H. and Mayol-Bracero, O. M.: Impact of long-range transported African dust on cloud water chemistry at a tropical montane cloud forest in northeastern Puerto Rico. Aerosol and Air Quality Research. DOI: 10.4209/aaqr.2015.05.0320, 2016.

Vinoj, V., Babu, S. S., Satheesh, S. K., Krishna Moorthy, K., and Kaufman, Y. J.: Radiative forcing by aerosols over

5 the Bay of Bengal region derived from shipborne, island-based, and satellite (Moderate-Resolution Imaging Spectroradiometer) observations, J. Geophys. Res., 109, D05203, doi: 10.1029/2003JD004329, 2004.

Warneck, P.: Chemistry of the Natural Atmosphere, San Diego CA, Academic Press, 1988.

Wex, H., Dieckmann, K., Roberts, G. C., Conrath, T., Izaguirre, M. A., Hartmann, S., Herenz, P., Schäfer, M., Ditas, F., Schmeissner, T., Henning, S., Wehner, B., Siebert, H., and Stratmann, F.: Aerosol arriving on the Caribbean island of

Barbados: physical properties and origin, Atmos. Chem. Phys., 16, 14 107-14 130, doi: 10.5194/acp-16-14107-2016, 2016.

Winter, B. and Chylek, P.: Contribution of sea salt aerosol to the planetary clear-sky albedo, Tellus B, 49(1), 72-79, 1997.

WMO/GAW Aerosol Measurement Procedures, Guidelines and Recommendations, 2nd Edition, 2016. (GAW No. 227,

WMO- No. 1177, http://www.wmo.int/pages/prog/arep/gaw/documents/FINAL_GAW_227.pdf).

Woodcock A. H.: Salt nuclei in marine air as a function of altitude and wind force, J. Meteorol, 10, 362-371, 1953. 
Atmos. Chem. Phys. Discuss., https://doi.org/10.5194/acp-2018-791

Manuscript under review for journal Atmos. Chem. Phys.

Atmospheric

Chemistry

Discussion started: 7 August 2018

(C) Author(s) 2018. CC BY 4.0 License.

and Physics

Discussions

(c) (i)

Table 1. Summary of the criteria to classify natural atmospheric aerosols in Puerto Rico.

Aerosol categories

\begin{tabular}{|c|c|c|c|c|c|c|c|}
\hline Criteria & $\mathrm{CM}$ & CMS & VA & $\mathrm{AD}$ & NA & SA & Unknown \\
\hline$\sigma_{\mathrm{sp}}$ & $<20 \mathrm{Mm}^{-1}$ & $>20 \mathrm{Mm}^{-1}$ & N/A & N/A & N/A & N/A & N/A \\
\hline$\sigma_{\mathrm{ap}}$ & $<0.6 \mathrm{Mm}^{-1}$ & $<0.6 \mathrm{Mm}^{-1}$ & N/A & N/A & N/A & N/A & N/A \\
\hline AOD & $<0.1$ & $>0.1$ & N/A & N/A & N/A & N/A & N/A \\
\hline $\begin{array}{l}\text { HYSPLIT BT } \\
\text { at } 100,500, \\
1000 \mathrm{~m}, \\
\text { AGL at } 06 \\
\text { and } 12 Z\end{array}$ & $\begin{array}{l}\text { Not over land 3- } \\
4 \text { days before } \\
\text { arrival to PR }\end{array}$ & $\begin{array}{l}\text { Not over land } \\
3-4 \text { days } \\
\text { before } \\
\text { arrival to PR }\end{array}$ & $\begin{array}{l}\text { SE or across } \\
\text { VA areas } \\
\text { last 1-3 days }\end{array}$ & E-SE last 5-7 days & $\begin{array}{l}\text { NW last } \\
4-7 \text { days }\end{array}$ & SW-SSE & N/A \\
\hline $\begin{array}{l}\text { Cloud streaks (if } \\
\text { present) }\end{array}$ & $\begin{array}{l}\text { WNW-ENE } \\
\text { small }\end{array}$ & $\begin{array}{l}\text { WNW-ENE } \\
\text { elongated }\end{array}$ & SE-NW & E-SE & N/A & N/A & \\
\hline $\begin{array}{l}\text { MODIS } \\
\text { Terra/Aqua }\end{array}$ & $\begin{array}{l}\text { Dark blue ocean } \\
\text { color with a few } \\
\text { or no white caps. }\end{array}$ & $\begin{array}{l}\text { Dark blue } \\
\text { ocean with } \\
\text { larger } \\
\text { number of } \\
\text { white caps }\end{array}$ & $\begin{array}{l}\text { Show VA } \\
\text { emissions }\end{array}$ & $\begin{array}{l}\text { Dust observed } \\
\text { leaving Africa 5- } \\
7 \text { days before } \\
\text { dust observed } \\
\text { over CPR. Brown } \\
\text { color. No VA } \\
\text { observed. }\end{array}$ & N/A & N/A & $\begin{array}{l}\text { Overcast } \\
\text { skies } \\
\text { observed or } \\
\text { lack of } \\
\text { MODIS } \\
\text { images }\end{array}$ \\
\hline SAL images & $\begin{array}{l}\text { No dust } \\
\text { suggested over } \\
\text { CPR }\end{array}$ & $\begin{array}{l}\text { No dust } \\
\text { suggested } \\
\text { over CPR } \\
\end{array}$ & $\begin{array}{l}\text { No dust } \\
\text { suggested } \\
\text { over CPR }\end{array}$ & $\begin{array}{l}\text { Dust suggested over } \\
\text { CPR }\end{array}$ & \begin{tabular}{|l|}
$\begin{array}{l}\text { No dust } \\
\text { suggested } \\
\text { over CPR }\end{array}$ \\
\end{tabular} & $\begin{array}{l}\text { No dust } \\
\text { suggested } \\
\text { over CPR }\end{array}$ & N/A \\
\hline
\end{tabular}

5

$\mathrm{CM}$ is clean marine, CMS is clean marine with greater sea salt content, VA is volcanic ash, AD is African dust, NA is North America, SA is South America. Unknown means the category could not be defined. 
Atmos. Chem. Phys. Discuss., https://doi.org/10.5194/acp-2018-791

Manuscript under review for journal Atmos. Chem. Phys.

Discussion started: 7 August 2018

(c) Author(s) 2018. CC BY 4.0 License.

\section{(c) (i)}

Atmospheric

Chemistry

and Physics

Discussions

Table 2. Flowchart to complement Table 1

5

10

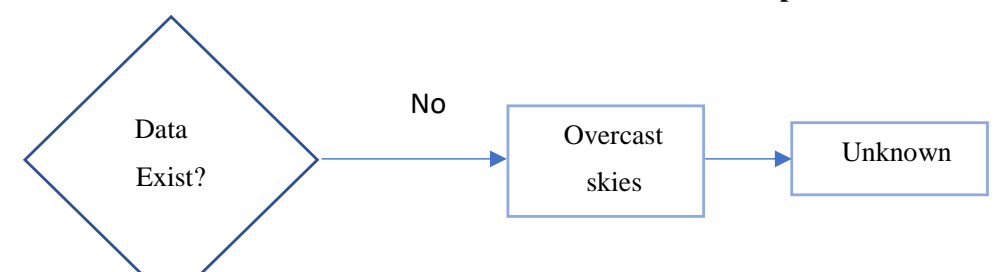

15

20

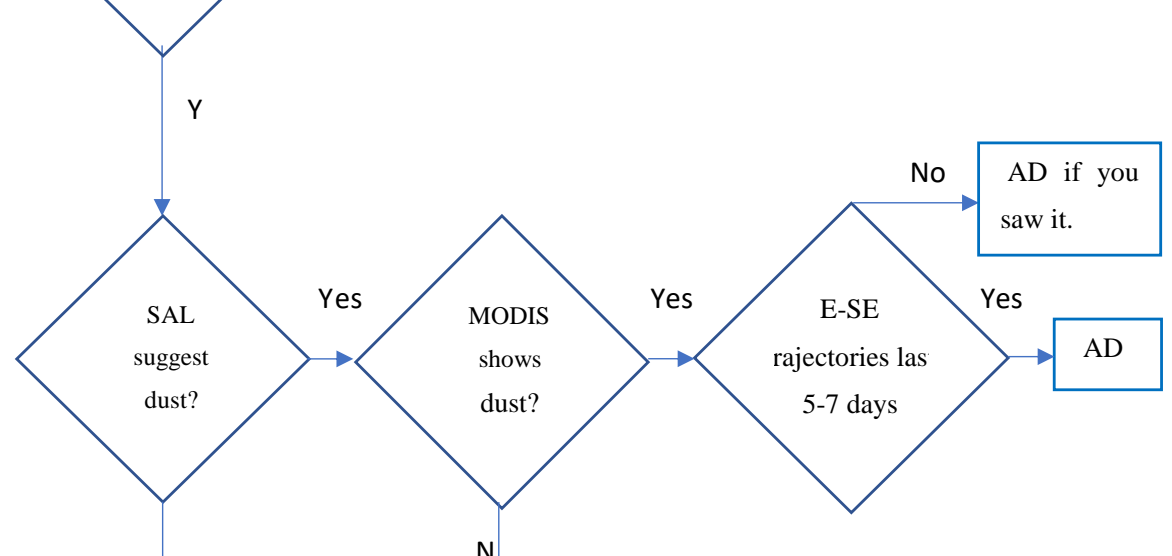

N

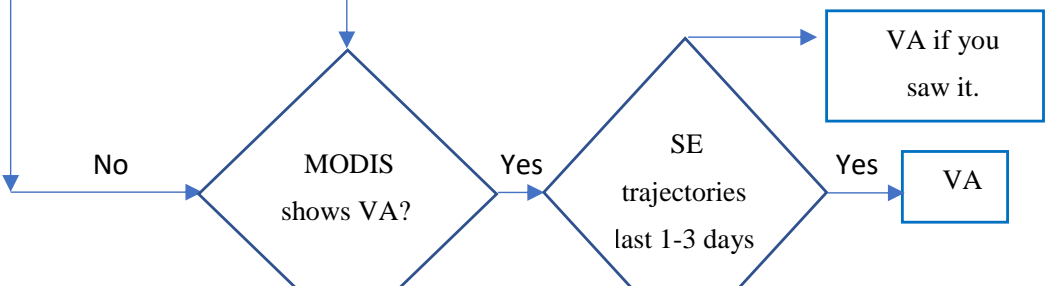
to

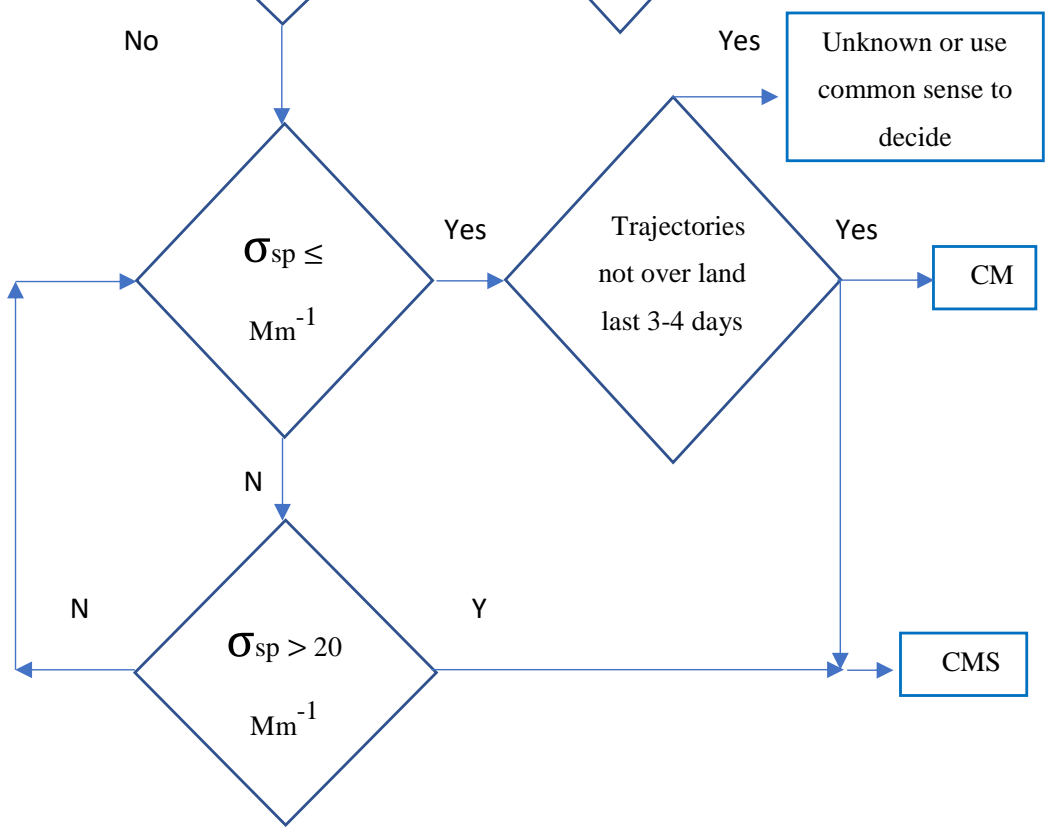


Atmos. Chem. Phys. Discuss., https://doi.org/10.5194/acp-2018-791

Manuscript under review for journal Atmos. Chem. Phys.

Discussion started: 7 August 2018

(c) Author(s) 2018. CC BY 4.0 License.

Table 3. Aerosol optical properties by aerosol category. Overall measurement results for means \pm statistical standard deviation. Values in parenthesis are the number of daily averages. The left column says if the variable is extensive, intensive, at the surface or columnar. All calculated values are for $\lambda=550 \mathrm{~nm}$ except $\stackrel{a}{\text { and }} \sigma_{a p}$, calculated for the $550 / 700 \mathrm{~nm}$ wavelength pair. AOD was assessed at $500 \mathrm{~nm}$.

\begin{tabular}{cccccc}
\multicolumn{7}{c}{ Aerosol category } \\
1. Extensive & CM & CMS & VA & AD & ALL \\
a. surface & & & & & \\
\hline$\sigma_{s p}\left(\mathrm{Mm}^{-1}\right)$ & $15.6 \pm 3.21(110)$ & $27.3 \pm 6.10(109)$ & $30.9 \pm 15.9(150)$ & $52.8 \pm 34.2(362)$ & $33.4 \pm 26.7(731)$ \\
$\sigma_{a p}\left(\mathrm{Mm}^{-1}\right)$ & $0.51 \pm 0.17(32)$ & $0.54 \pm 0.22(26)$ & $1.26 \pm 1.20(80)$ & $1.83 \pm 1.51(324)$ & $1.6 \pm 1.5(462)$ \\
\hline b. columnar & & & & & \\
\hline AOD & $0.09 \pm 0.03(41)$ & $0.13 \pm 0.031(39)$ & $0.21 \pm 0.061(60)$ & $0.45 \pm 0.17(179)$ & $0.28 \pm 0.15(319)$ \\
\hline
\end{tabular}

\begin{tabular}{llllll}
\hline $\begin{array}{l}\text { 2. Intensive } \\
\text { a. columnar }\end{array}$ & & & & \\
\hline AODFF & $0.21 \pm 0.091(41)$ & $0.19 \pm 0.11(39)$ & $0.35 \pm 0.16(60)$ & $0.26 \pm 0.15(179)$ & $0.27 \pm 0.16(319)$ \\
\hline b. surface & & & & \\
\hline$R_{s p}$ & $0.15 \pm 0.04(110)$ & $0.14 \pm 0.05(101)$ & $0.26 \pm 0.11(150)$ & $0.23 \pm 0.09(358)$ & $0.22 \pm 0.10(719)$ \\
$R_{a p}$ & $0.62 \pm 0.14(51)$ & $0.63 \pm 0.17(23)$ & $0.65 \pm 0.11(64)$ & $0.39 \pm 0.18(209)$ & $0.48 \pm 0.24(347)$ \\
$\therefore$ & $0.33 \pm 0.16(110)$ & $0.33 \pm 0.18(101)$ & $0.63 \pm 0.49(150)$ & $0.44 \pm 0.34(358)$ & $0.46 \pm 0.36(719)$ \\
$\omega_{0}$ & $0.99 \pm 0.01(76)$ & $0.99 \pm 0.01(70)$ & $0.96 \pm 0.03(82)$ & $0.96 \pm 0.02(330)$ & $0.96 \pm 0.03(558)$ \\
$\Delta R F / A O D\left(\mathrm{Wm}^{-2}\right)$ & $-28 \pm 0.061(76)$ & $-27 \pm 0.75(70)$ & $-27 \pm 1.1(82)$ & $-26 \pm 0.87(331)$ & $-26.7 \pm 1.25(559)$ \\
\hline
\end{tabular}


Atmos. Chem. Phys. Discuss., https://doi.org/10.5194/acp-2018-791

Manuscript under review for journal Atmos. Chem. Phys.

Discussion started: 7 August 2018

(c) Author(s) 2018. CC BY 4.0 License.
Atmospheric

Chemistry and Physics

Discussions

(c) $\underset{\mathrm{Br}}{(i)}$
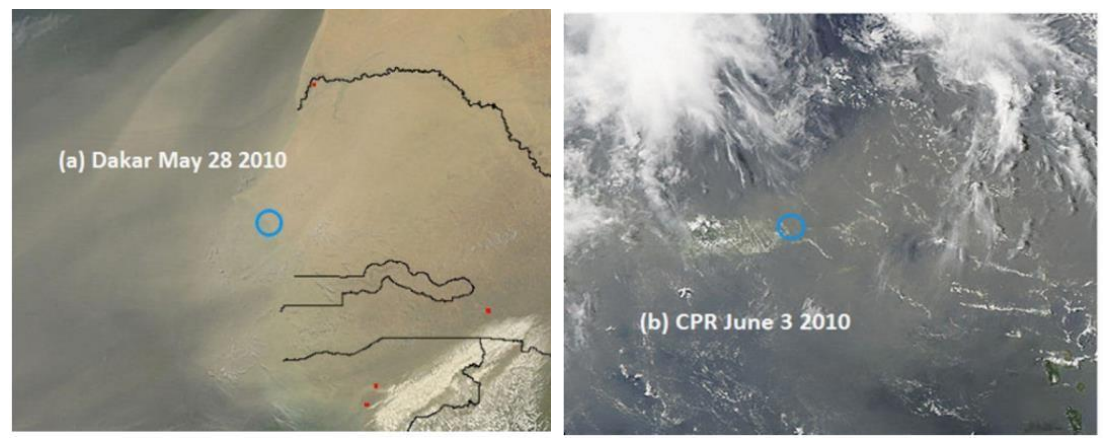

Figure 1. (a) African dust cloud over Dakar, Africa. (b) African dust cloud over Puerto Rico, the Caribbean and Atlantic. (Source: https://aeronet.gsfc.nasa.gov/cgi-bin/bamgomas_interactive)

5

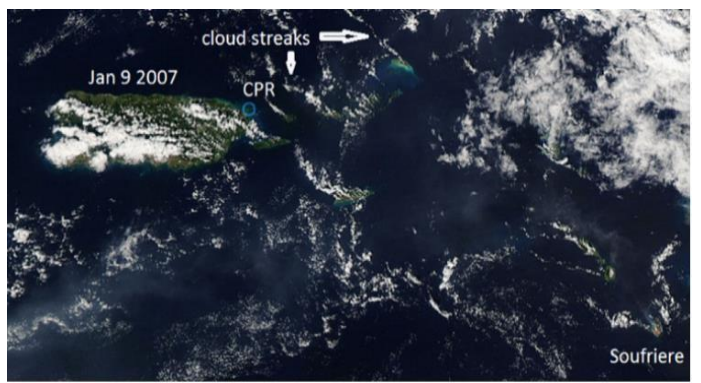

Figure 2. Volcanic ash reaching Puerto Rico under a southeast flow.

(Source: https://aeronet.gsfc.nasa.gov/cgi-bin/bamgomas interactive)

10

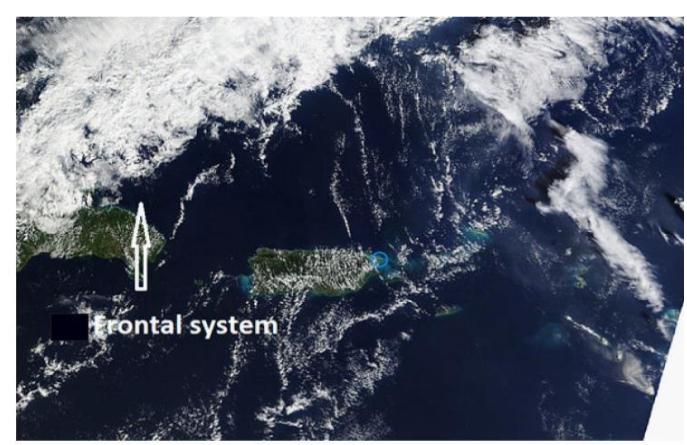

Figure 3. Volcanic ash plume northeast of Puerto Rico.

(Source: https://aeronet.gsfc.nasa.gov/cgi-bin/bamgomas_interactive) 
Atmos. Chem. Phys. Discuss., https://doi.org/10.5194/acp-2018-791

Manuscript under review for journal Atmos. Chem. Phys.

Discussion started: 7 August 2018

(c) Author(s) 2018. CC BY 4.0 License.
Atmospheric

Chemistry

and Physics

Discussions
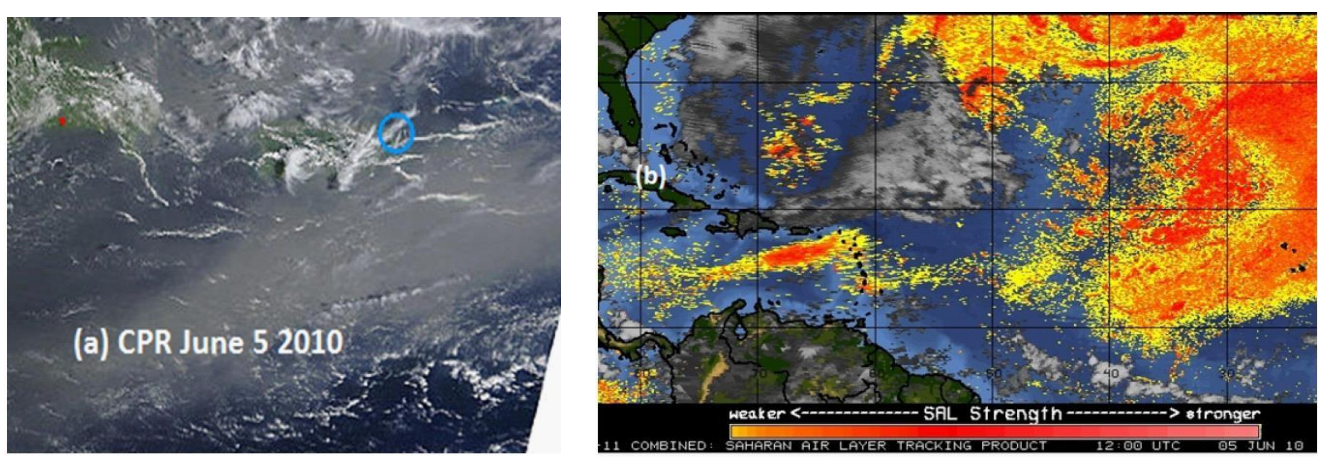

Figure 4. (a) Dust cloud over Puerto Rico and adjacent waters June 5, 2010. (b) SAL image June 5, 2010.

(Source: (a) https://aeronet.gsfc.nasa.gov/cgi-bin/bamgomas_interactive, (b) http://tropic.ssec.wisc.edu/archive/).

5
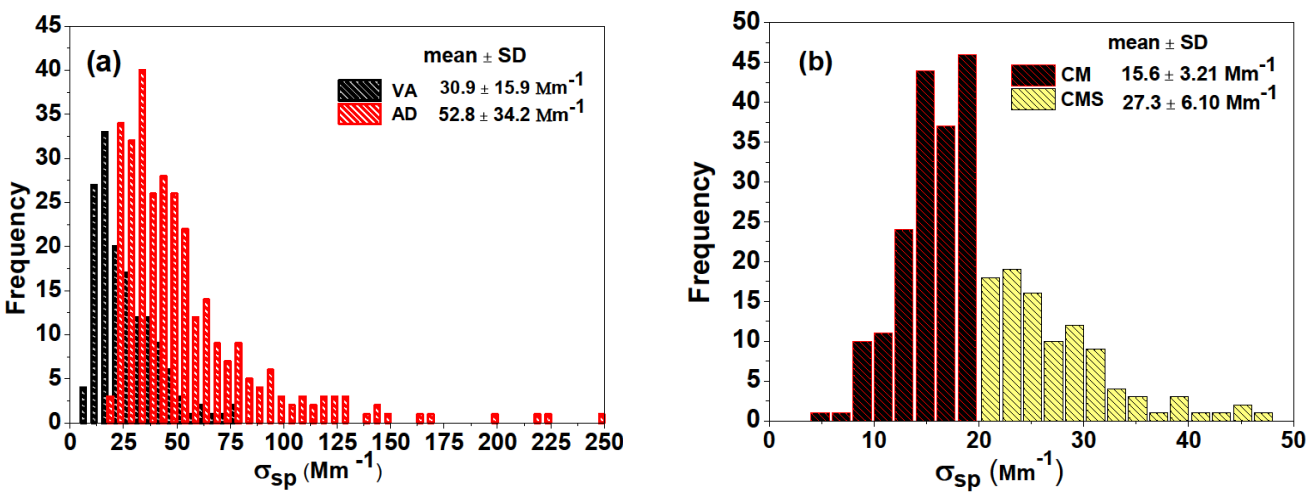

Figure 5. (a) Frequency distribution of the scattering coefficient $\sigma_{\mathrm{sp}}$, for AD and for VA. (b) for CM and for CMS. 
Atmos. Chem. Phys. Discuss., https://doi.org/10.5194/acp-2018-791

Manuscript under review for journal Atmos. Chem. Phys.

Discussion started: 7 August 2018

(c) Author(s) 2018. CC BY 4.0 License.
Atmospheric

Chemistry

and Physics

Discussions
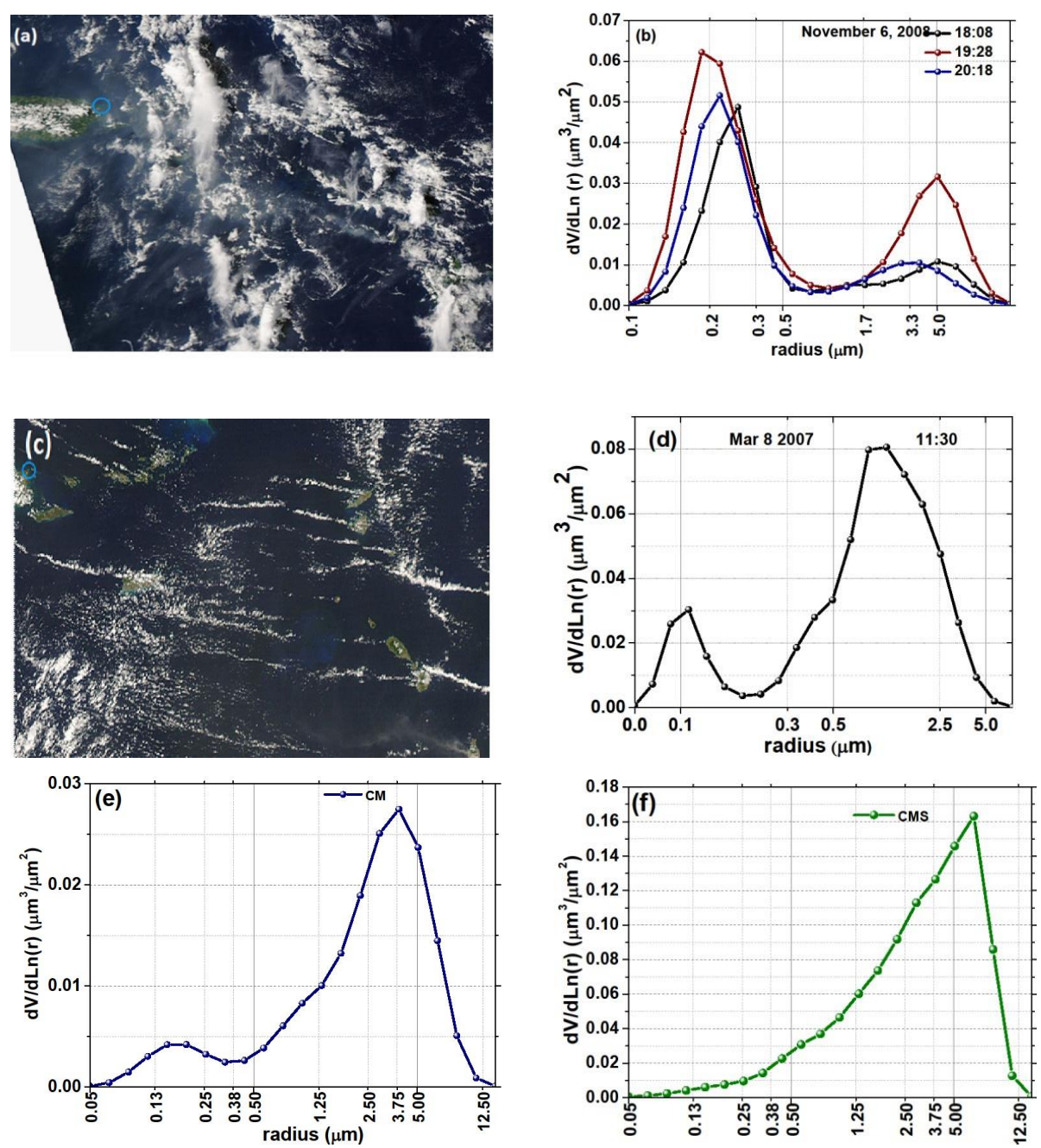

5

Figure 6. (a) Volcanic ash event over CPR in November 6, 2008. (b) Volume size distribution at various times in November 6, 2008. (c) Volcanic ash event on March 8, 2007. (d) Volume size distribution corresponding to the event on March 8, 2007. (e) Mean volume size distribution for the CM category. (f) Mean volume size distribution for the CMS category. (Source: Figures 7 (a) and (c) https://aeronet.gsfc.nasa.gov/cgibin/bamgomas_interactive) 
Atmos. Chem. Phys. Discuss., https://doi.org/10.5194/acp-2018-791

Manuscript under review for journal Atmos. Chem. Phys.

Discussion started: 7 August 2018

(c) Author(s) 2018. CC BY 4.0 License.
Atmospheric

Chemistry

and Physics

Discussions

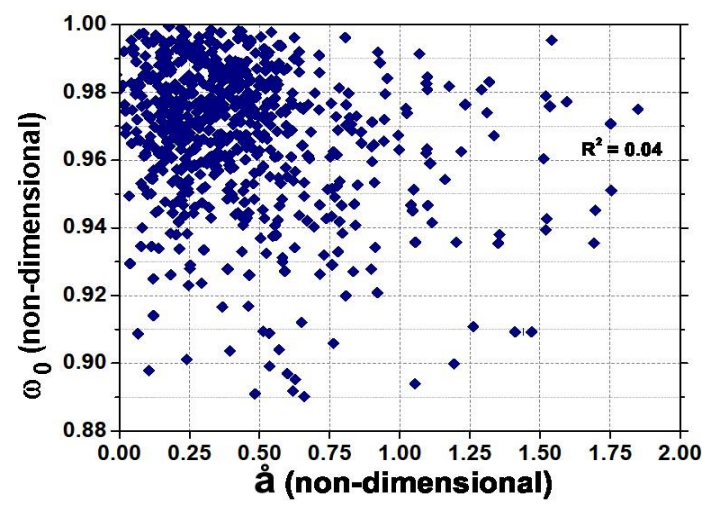

Figure 7. Variation of the single scattering albedo with the Ångström exponent (å).
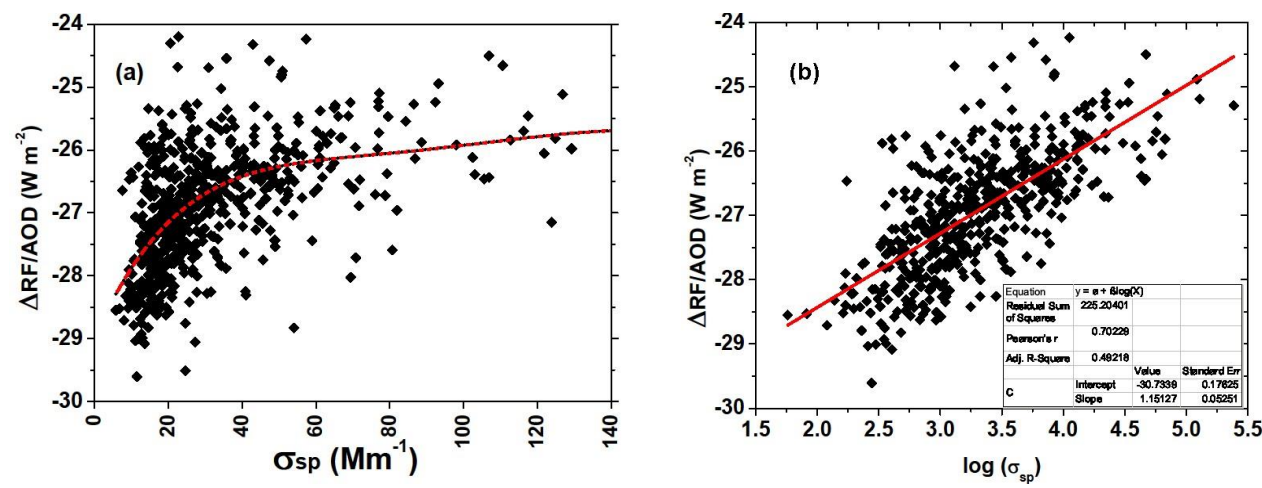

Figure 8. (a) Variability of the radiative forcing efficiency $\triangle \mathrm{RF} / \mathrm{AOD}$ with the scattering coefficient $\sigma_{\mathrm{sp}}$. (b) Variability of the radiative forcing efficiency $\triangle \mathrm{RF} / \mathrm{AOD}$ with the natural logarithm of $\sigma_{\mathrm{sp}}$.

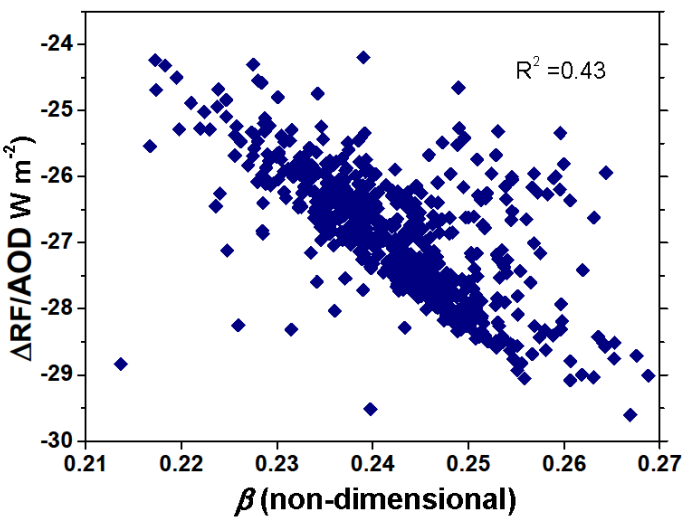

Figure 9. Variability of $\triangle \mathrm{RF} / \mathrm{AOD}$ with the size dependent $\beta$. 
Atmos. Chem. Phys. Discuss., https://doi.org/10.5194/acp-2018-791

Manuscript under review for journal Atmos. Chem. Phys.

Discussion started: 7 August 2018

(C) Author(s) 2018. CC BY 4.0 License.
Atmospheric

Chemistry

and Physics

Discussions

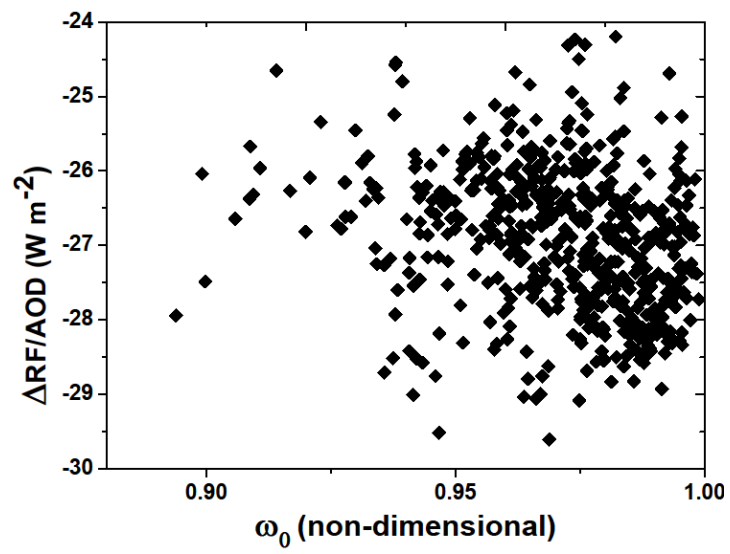

Figure 10 . Variability of the Radiative forcing efficiency $\triangle \mathrm{RF} / \mathrm{AOD}$ as a function of the single scattering albedo $\left(\omega_{0}\right)$.
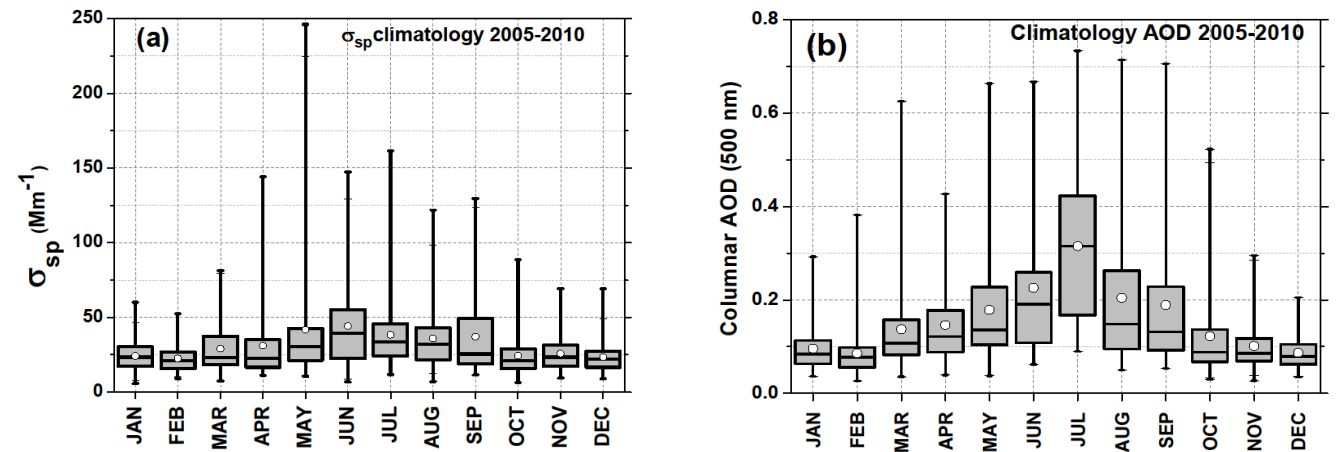

Figure 11. (a) Climatology of the scattering coefficient $\left(\sigma_{\mathrm{sp}}\right)$. (b) Climatology of the columnar optical depth (AOD) using daily averages.

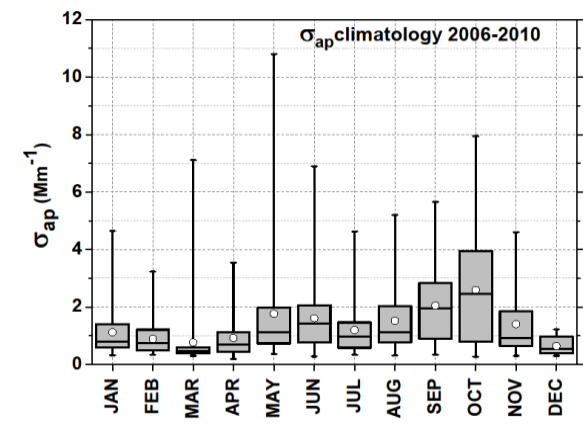

Figure 12. Climatology of $\sigma_{\text {ap }}$ using daily averages. 
Atmos. Chem. Phys. Discuss., https://doi.org/10.5194/acp-2018-791

Manuscript under review for journal Atmos. Chem. Phys.

Discussion started: 7 August 2018

(C) Author(s) 2018. CC BY 4.0 License.
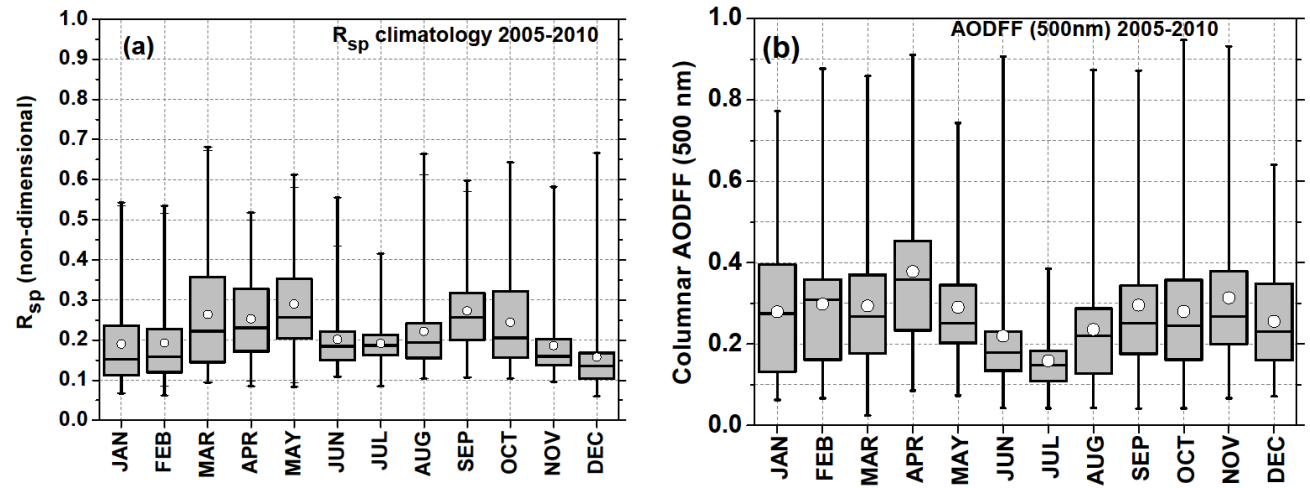

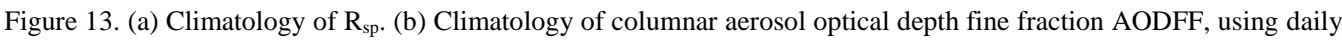
averages.

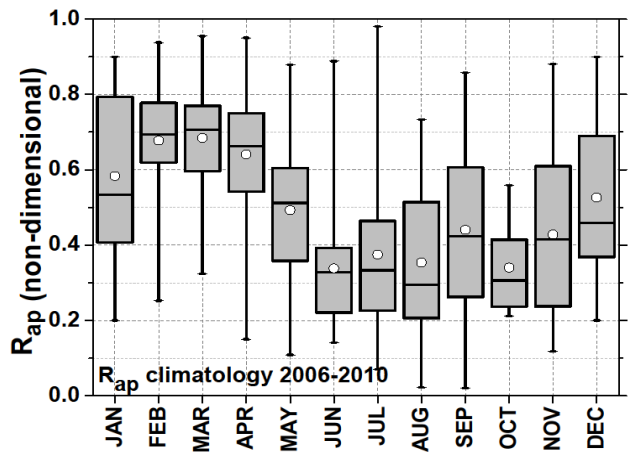

Figure 14. Climatology of $\mathrm{R}_{\mathrm{ap}}$ using daily averages.
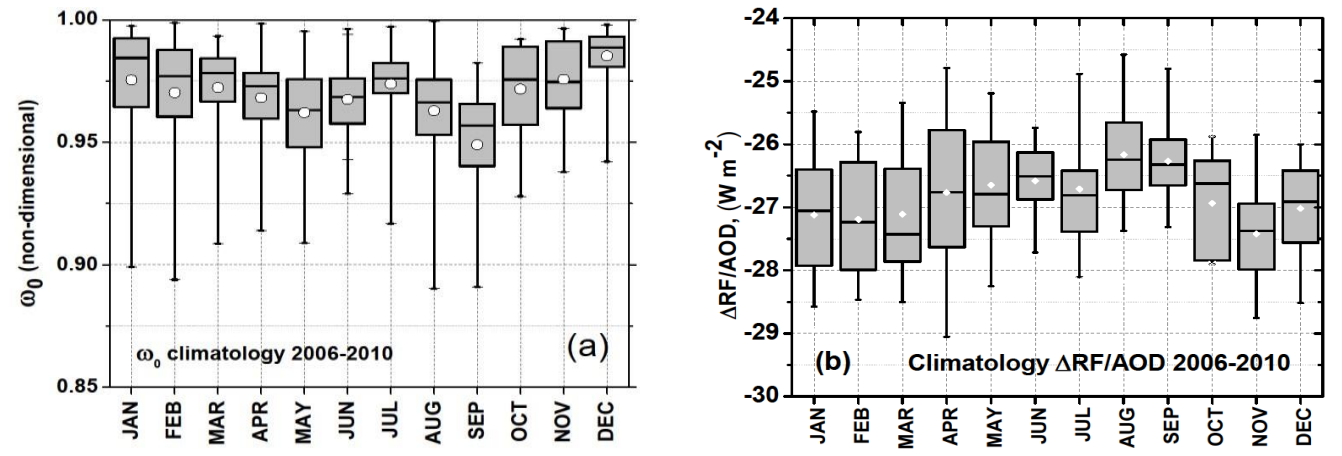

Figure 15. (a) Climatology of $\omega_{0}$ and (b) Climatology of $\triangle \mathrm{RF} / \mathrm{AOD}$ using daily averages. 